\title{
Comparison of the Blind Snake Populations, Xerotyphlops vermicularis (Merrem, 1820) (Squamata: Typhlopidae) in Turkey and Cyprus: Morphology, Serology, Ecology, and Geometric Morphometrics
}

\author{
Bahadır AKMAN ${ }^{*}$, Bayram GÖÇMEN ${ }^{\dagger}$,
}

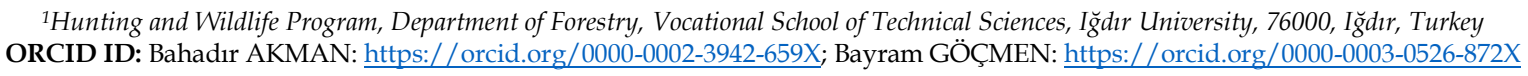

\begin{tabular}{|c|c|c|}
\hline Received: 04.02.2019 & Published online: 30.06 .2019 & Issue published: 30.06 \\
\hline \multicolumn{3}{|c|}{$\begin{array}{l}\text { Abstract: In this study, different populations of Xerotyphlops vermicularis were investigated comparatively regarding to the } \\
\text { morphology, serology, ecology, and geometric morphometric analyses. For this purpose, } 351 \text { specimens from Turkey }(\mathrm{n}=275) \\
\text { and Cyprus }(\mathrm{n}=76) \text { were evaluated. As a result of the morphology, serology, coloration, and geometric morphometric analyses, } \\
\text { it was determined that there were no differences amongst the populations located in Anatolia. However, between the } \\
\text { Anatolian and Cyprian populations, we detected some differences. These populations can be distinguished from each other in } \\
\text { terms of some pholidolial characteristics and geometric morphometrics. Therefore, it is suggested that there is a requirement } \\
\text { to describe a new subspecies for the Cyprus population. }\end{array}$} \\
\hline
\end{tabular}

Keywords: Xerotyphlops, Xerotyphlops vermicularis, blind snake, Anatolia, Cyprus.

Türkiye ve Kıbrıs Adasında Dağılış Gösteren Kör Yılan, Xerotyphlops vermicularis Merrem, 1820 (Squamata: Typhlopidae) Populasyonlarının Morfolojik, Serolojik, Ekolojik ve Geometrik Morfometrik Yönden Karşılaştırılması

Öz: Bu çalışmada, Xerotyphlops vermicularis populasyonları morfoloji, seroloji, ekoloji ve geometrik morfometrik çalışmaları açısından karşılaştırılmıştır. Bu amaçla, Türkiye $(n=275)$ ve Kıbrıs'tan ( $n=76)$ toplanan 351 örnek çalışılmıştır. Morfoloji, seroloji, renklenme ve geometrik morfometrik analizler sonucunda Anadolu'da bulunan populasyonlar arasında fark olmadiğı tespit edilmiştir. Ancak, Anadolu ve Kıbrıs popülasyonları arasında bazı farklılıklar tespit edilmiş ve bu popülasyonlar bazı pholidolial özellikler ve geometrik morfometrik çalışmalarıyla birbirinden ayırt edilebilmiştir. Dolayısıyla bu güne kadar monotipik olarak bilinen türün Kıbrıs Adası'nda yaşayan populasyonunun farklı bir takson adı altında isimlendirilmesinin uygun olduğu ortaya çıkmıştır.

Anahtar kelimeler: Xerotyphlops, Xerotyphlops vermicularis, kör yılan, Anadolu, Kıbrıs.

\section{Introduction}

There are about 2700 snake species within the suborder Serpentes that is divided into two infraorders as Alethinophidia and Scolecophidia (Rage, 1987; Greene, 1997; Pough, Janis, \& Heiser, 1999; Afroosheh, RastegarPouyani, Ghoreishi, \& Kami, 2013). Of these two major divisions of snakes, Scolecophidia is the most poorly known group in terms of the species' diversity, phylogeny, biogeography, and ecology (Greene, 1997; Kornilios et al., 2012). Scolecophidians include approximately 400 species and are divided into three families as Anomalepidae, Leptotyphlopidae, and Typhlopidae (Niyomwan, Thirakhupt, \& Nabhitabhata, 2001; Vidal et al., 2010). In Turkey, one species of Leptotyphlopidae and two species of Typhlopidae are found. These three species are Myriopholis macrorhyncha (Jan, 1860), Letheobia episcopus (Franzen \& Wallach, 2002), and Xerotyphlops vermicularis (Merrem, 1820) (Franzen \& Wallach, 2002; Budak \& Göçmen, 2005; Göçmen et al., 2009; Hedges, Marion, Lipp, Marin, \& Vidal, 2014; Afsar, Çiçek, Tayhan, \& Tok, 2016).

$$
\text { Within Scolecophidians, Typhlopidae }
$$
(approximately 260 species) occur in Africa, Madagascar, southern Asia, South and Central America, and Australia, while only one representative, Xerotyphlops vermicularis, is found in southeastern Europe (Başoğlu \& Baran, 1980; Baran \& Atatür, 1998; Cox, Chanson, \& Stuart, 2006; Adalsteinsson, Branch, Trape, Vitt, \& Hedges, 2009; Vidal et al., 2010; Kornilios et al., 2012; Afroosheh et al., 2013; Jablonski \& Balej, 2015). Many different climatic regions and vegetation types are seen in Anatolia that has an important role for $X$. vermicularis' dispersal behaviour. Because of its position and geological history, Anatolia acted in the past as a bridge or as a barrier for species' dispersal between Asia, Europe, and the Ethiopian region via the Middle East, providing a natural pathway or acting as a vicariant agent (Tchernov, 1992; Kornilios et al., 2011). There are limited studies on $X$. vermicularis, according to the IUCN; thus, further research towards its biology, ecology, population numbers, and geographic range are needed (Kornilios et al., 2011; Afsar et al.,2016).

The present study reports morphological, serological, ecological, and geometric morphometric comparisons among the Anatolian populations and between the Anatolian and the Cyprian populations of Xerotyphlops vermicularis. 


\section{Material and Methods}

Several field trips were performed in activity seasons of the reptiles (April 2007-August 2013) to determine the distribution range of Xerotyphlops vermicularis in all regions of Turkey and Cyprus. During our field studies, various biotope types (karstic, volcanic, sandy, clayey, stony soily, and rocky) were surveyed to include various types of vegetation.

During our scientific excursions, 163 specimens were collected in Anatolia (112 specimens) and Cyprus (51 specimens). Field trips were usually done with a team of 3-4 people and data on color patterns (and photos) were recorded from living animals. The specimens were kept alive for a short time (approximately one month) in a terrarium for coloration analyses and photography (Olympus C-5060WZ and Nikon Coolpix 5400). The specimens were fixed and stored in $96 \%$ ethanol in order to keep the DNA material more stable for future molecular phylogeny studies (Göçmen et al., 2007) and deposited in the Zoology Museum of Adryaman University (ZMADYU) in Adiyaman, Turkey. However, 188 specimens were borrowed from ZDEU (Zoology Department of Ege University) and ZMADYU (Zoology Museum of Adiyaman University). The list of the materials examined is given in Appendix and localities are mapped (Fig. 1).

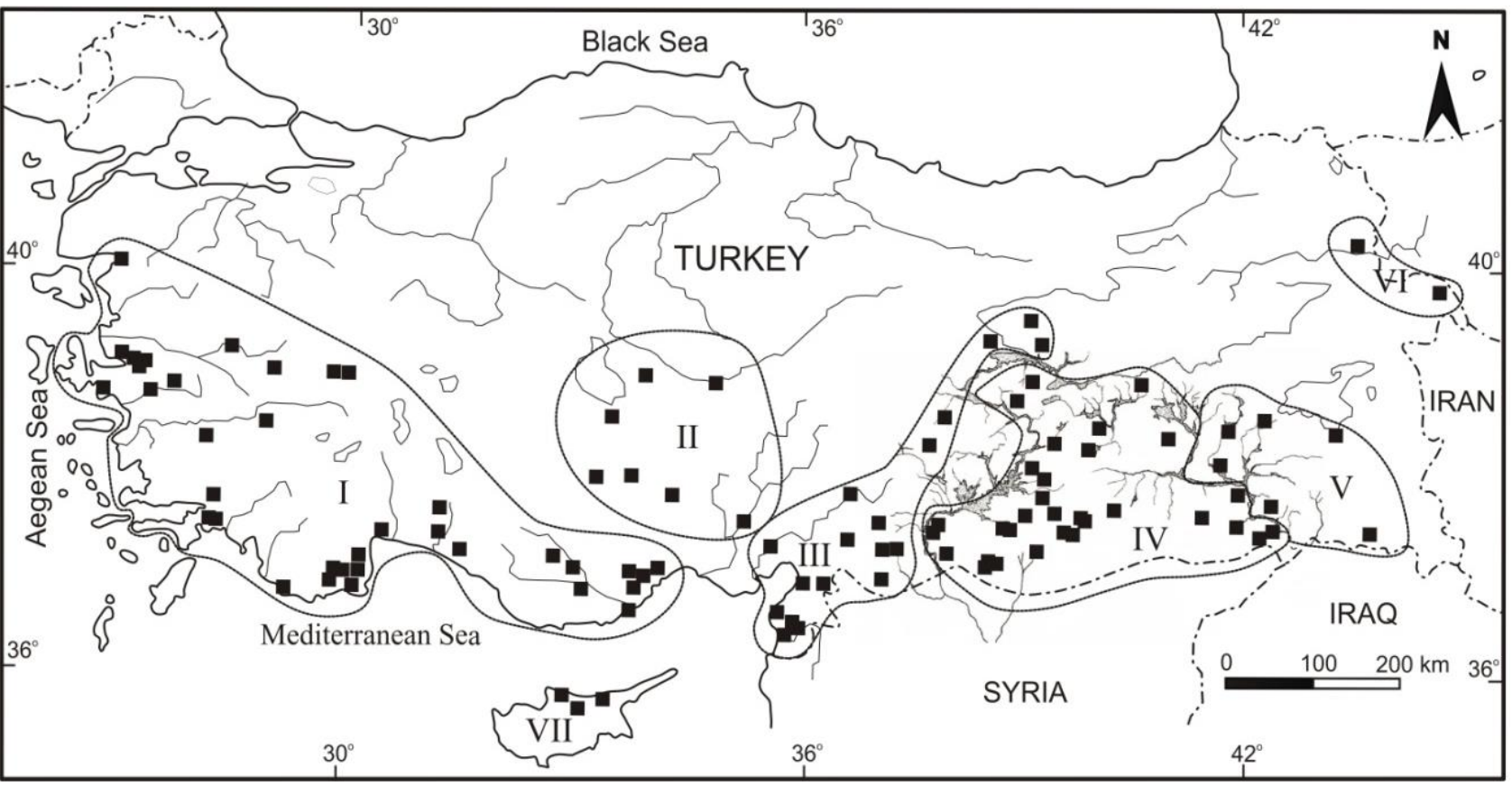

Figure 1: Map showing the localities where the specimens were collected (solid square: localities of materials).

Blood samples $(n=33)$ were taken for serological analyses. The separation of blood-serum proteins was achieved following the polyacrylamide "disc" gel electrophoresis method of Davis (1964), slightly modified by Özeti and Atatür (1979). As a result of the serological analysis, according to the blood serum protein numbers, it was determined that the Anatolian and the Cyprian populations of Xerotyphlops vermicularis can be evaluated as 7 different groups. In the determination of the distribution boundaries of these groups, the Anatolian diagonal and its' extensions, the Tigris, and the Euphrates Rivers were taken as basis of ecological barriers.

\subsection{Morphometric Analyses}

For metric characters we used only adults, avoiding the effects of allometry (Moravec, Baha El Din, Seligmann, Naomi, \& Werner, 1999; Werner \& Seifan, 2006). Metric characters were measured using Mitutoyo digital calipers $( \pm 0.02 \mathrm{~mm})$, except rostrum-anus length and tail length that were measured by a millimetric ruler. For meristic characters, we used both adult and juvenile individuals. Several meristic characters were examined bilaterally and right and left sides were compared to verify the possible presence of directional asymmetry (Werner, 1971; Werner
\& Seifan, 2006). Further, means of the right and left sides were used to express the value for each individual. These characters are indicated by an asterisk $\left(^{*}\right)$ in the character list below. Metric and meristic characters were measured and counted under a stereo microscope. All of the specimens were studied without differentiating the sex avoiding to damage the specimens for further studies as the sex in typhlopids can only be determined by dissection.

Statistics were carried out using SPSS v.15.0. Before the statistical analyses, raw data were transformed [log (x)] for metric and meristic characters, and arctan for indexes. For comparison of all characters, Discriminant Analysis (Mahalanobis Distance) and Student T-Test were also conducted. Furthermore, to control the test results of raw data, data of raw metric characters were again put to statistical analyses, taking index values of PERCRA (percent of rostrum-anus length; [each metric character/ RA] $\times 100)$, according to Werner (1971). In this way, the evaluations on similarities or differences between the populations were strengthened. The evaluations of all statistical analyses were based on the statistical significance level of " $p \leq 0.05$ ". 
Metric and meristic characters follow previously published methods on Typhlopidae (Niyomwan et al., 2001; Broadley \& Wallach, 2007; Thomas \& Hedges, 2007; Wallach, Brown, Diesmos, \& Gee, 2007; Afroosheh et al., 2013). They are as follows: rostrum-anus length (RA): distance from tip of snout to cloaca, tail length (TL): from cloaca to tip of tail (if complete), midbody diameter (MBD), midtail diameter (MTD), total body length (TBL): RA+TL, head length (HL): from snout tip to the posterior edge of the lower jaw, head radius (HR): the distance from the tip of the snout to a transverse line through the middle of both eyes, head width (HW): width of head at the level of the eyes, maximum head width (MHW): greatest width of head, maximum head depth (HD): greatest depth of head, rostral width (RW), rostral length (RL), distance from anterior of rostrale to eye level (DRE), internarial length (IL): distance between inner sides of nostrils, distance between the eyes (DBE), distance from anterior of nostril to posterior of eye (DNE), preocular width (PW): greatest width of preocular, preocular depth (PD): greatest depth of preocular, ocular width (OW): greatest width of oculare, ocular depth (OD): greatest depth of ocular, horizontal diameter of eye (ED), minimum distance from snout to posterior of eye (DSE), supralabials (S), infralabials (I), mid-body scales (MBS): longitudinal rows around mid-body; mid-tail scales (MTS): longitudinal rows around mid-tail, dorsocaudals (DC): the number of vertebral scales along the tail, subcaudals (SC): the number of midventral scales along the tail, middorsal scales (MDS): scales between the rostral and terminal spine. Dorsal and lateral aspects of head in Xerotyphlops vermicularis are shown in Fig. 2.
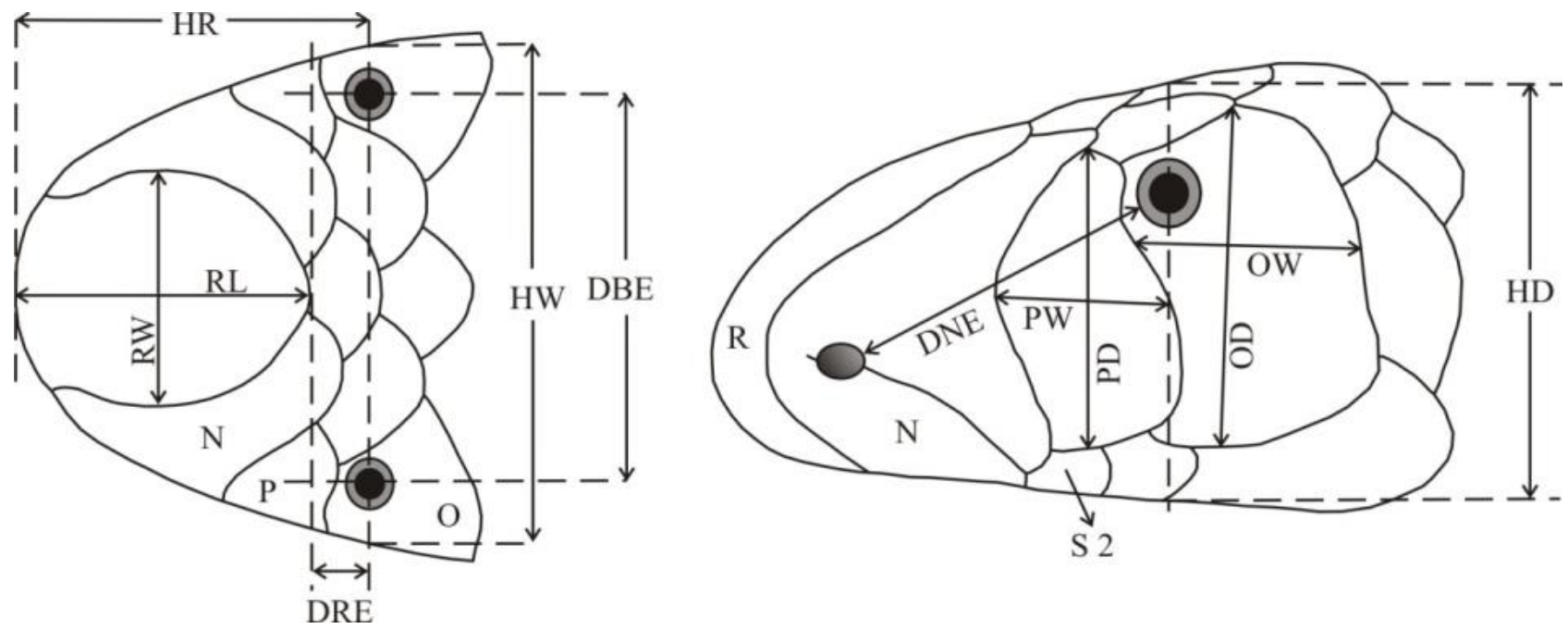

Figure 2: Dorsal (on the left) and lateral (on the right) aspects of head in Xerotyphlops vermicularis. S: supralabiale, N: nasale, O: ocular, P: preoculare, R: rostrale, other abbreviations are given above.

\subsection{Geometric Morphometric Analysis}

Images of 209 specimens were taken via digital camera (Olympus C-5060WZ) and the dorsal image of head was captured under a stereo microscope. All images were downloaded to a PC and a file in tps format was created for each of the groups studied using TpsUtil 1.44 (Rohlf, 2009). Two dimensional Cartesian coordinates of 15 landmarks from dorsal of head (Fig. 3) were digitized by Tps-Dig 2.12 (Rohlf, 2008; Kaliontzopoulou, Carretero, \& Llorente, 2007). Using the Tps-Small 1.20 software (Rohlf, 2003), we confirmed that shape variation between the specimens was sufficiently small and; therefore, the distribution of points in the shape space can be represented satisfactorily by their distribution in the tangent space. We then applied a Generalized Procrustes Analysis (GPA, Rohlf, \& Slice, 1990; Rohlf, 1999) using Integrated Morphometrics Package (IMP) (Zelditch, Swiderski, Sheets, \& Fink, 2007) CoordGen6f. By doing so, the differences between landmark configurations (scale, ordination, and orientation) were eliminated. The data was then examined according to its relative warps in TPSRELW 1.45 (Rohlf, 2007). The distribution of structural shape differences was shown on the first two principal components (PC) in PCAGen6p, IMP. In CVAGen6n, IMP canonical variates analysis was conducted and the distribution of individuals on the first two canonical variates $(\mathrm{CV})$ was obtained. By conducting Multivariate Analysis of Variance (MANOVA), the statistical significance of the distribution was analyzed and detection was made to see if there were any differences between the groups or not. The data that was standardized via GPA rotation in Morpheus (Slice, 2007) was summarized; then, the average values obtained from the same program were used to construct a dissimilarity tree using SAHN in the Numerical Taxonomy and Multivariate Analysis System (NTSYS) 2.10 Software (Rohlf, 2000; Barkan \& Aytekin, 2013).

\section{Results and Discussion}

\subsection{Distribution and Habitat}

As a result of the fieldwork, we found the specimen in all regions of Anatolia except Thrace part of Marmara region and the Black Sea region and also in Cyprus. In addition, a large part of the species distribution in Anatolia covers west, south, and southeast regions based on the localities in this study. During all of the field studies that were conducted between 2007 and 2013, it was observed that the species was active only when the temperature was between $17-38^{\circ} \mathrm{C}$ in the months from April to August. All specimens were collected during daytime under stones on 
dry, slightly moist, and stony slopes whose cover included both heavily degraded vegetation and dense stands of grasses and herbs (Fig. 4). Moreover, specimens were found in both karstic and volcanic basalt areas.

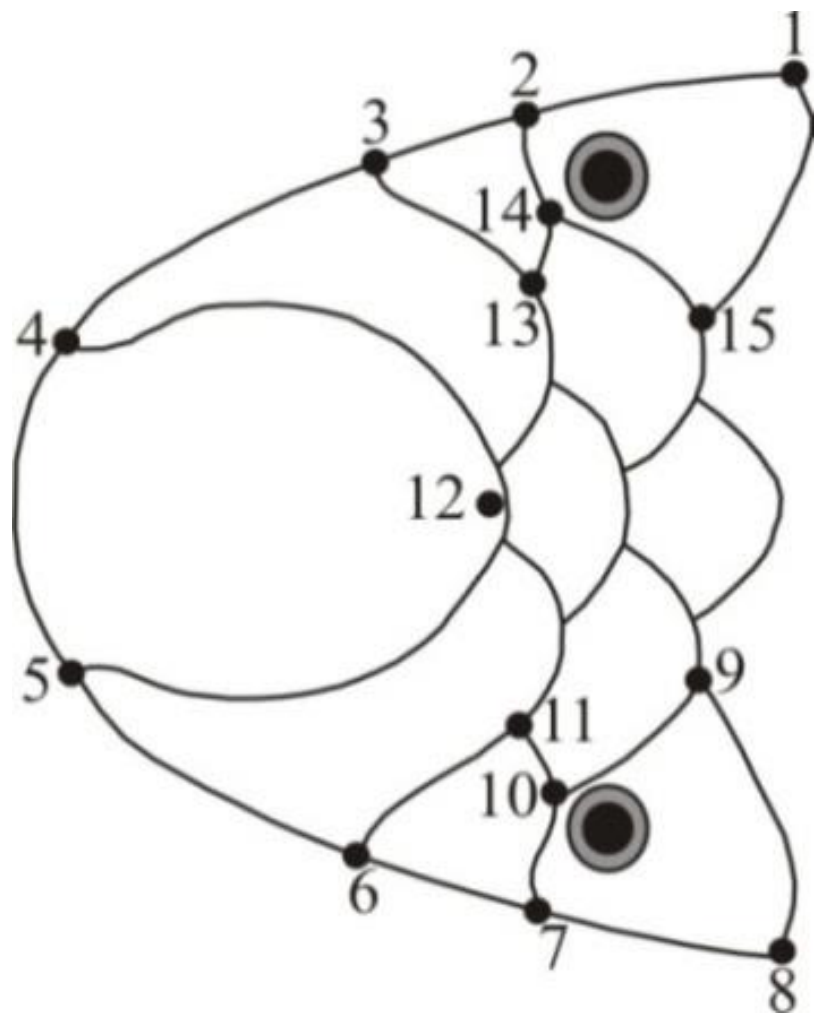

Figure 3: Location of the landmarks on the schematic head of Xerotyphlops vermicularis.

In terms of the habitat, there were not any differences between Xerotyphlops vermicularis populations from Anatolia and Cyprus. All observations during the field studies are consistent with the literature (Boulenger, 1913; Terent'ev \& Chernov, 1949; Haas, 1951; Mertens \& Wermuth, 1960; Helmich, 1962; Başoğlu \& Baran, 1980; Baran, 1981; Mattison, 1982; Disi, 1985; Osenegg, 1989; Esterbauer, 1992; Baran \& Atatür, 1998; Arıkan et al., 2000; Kumlutaş, Durmuş, \& Ilgaz, 2000; Atatür \& Göçmen, 2001; Kumlutaş et al., 2004; Hedges et al., 2014).

\subsection{Serological Observations and Analyses}

The protein distribution pattern of Anatolia $(n=28)$ and Cyprus specimens $(n=5)$ representing of the Xerotyphlops vermicularis populations studied is given in Figure 5 along with their densitometric tracing curves. The blood-serum protein fractions were found to be 12 (11 globulin, 1 albumin) in 6 specimens from Afyon, Antalya, İzmir, and Mersin provinces (Fig. 5a); 15 (14 globulin, 1 albumin) in 5 specimens from Konya provinces (Fig. 5b; 14 (13 globulin, 1 albumin) in 4 specimens from Adana, Hatay, and Kilis provinces (Fig. 5c); 11 (10 globulin, 1 albumin) in 5 specimens from Bingöl, Diyarbakır, and Şanlıurfa provinces (Fig. 5d); 15 (13 globulin, 1 postalbumin, 1 albumin) in 4 specimens from Bingöl, Diyarbakır, and Şanlıurfa provinces (Fig. 5e); 13 (12 globulin, 1 albumin) in 4 specimens from Kars and Iğdır provinces (Fig. 5f); and 12 (11 globulin, 1 albumin) in 5 specimens from Cyprus (Fig. 5f). In conclusion, the number of fractions ranged from 11 to 15 (Group I: 12, Group II: 15, Group III: 14, Group IV: 11, Group V: 15, Group VI: 13) in Anatolian populations. Although the number of fractions was equal in Group II and Group V, they differ in that the Group V has a postalbumin band.

In terms of the total numbers of protein bands and the density of each protein band, Cyprus population is similar to Antalya population. Accordingly, Anatolian populations could have a more complex composition according to the Cyprus populations. This condition points to a significant difference between the populations.

\subsection{Morphology and Morphometric Analyses}

In this study, 349 specimens were examined from Anatolia (236 adults and 37 juveniles) and Cyprus (66 adults and 10 juveniles). Two specimens from Anatolia were not examined as they were too damaged.
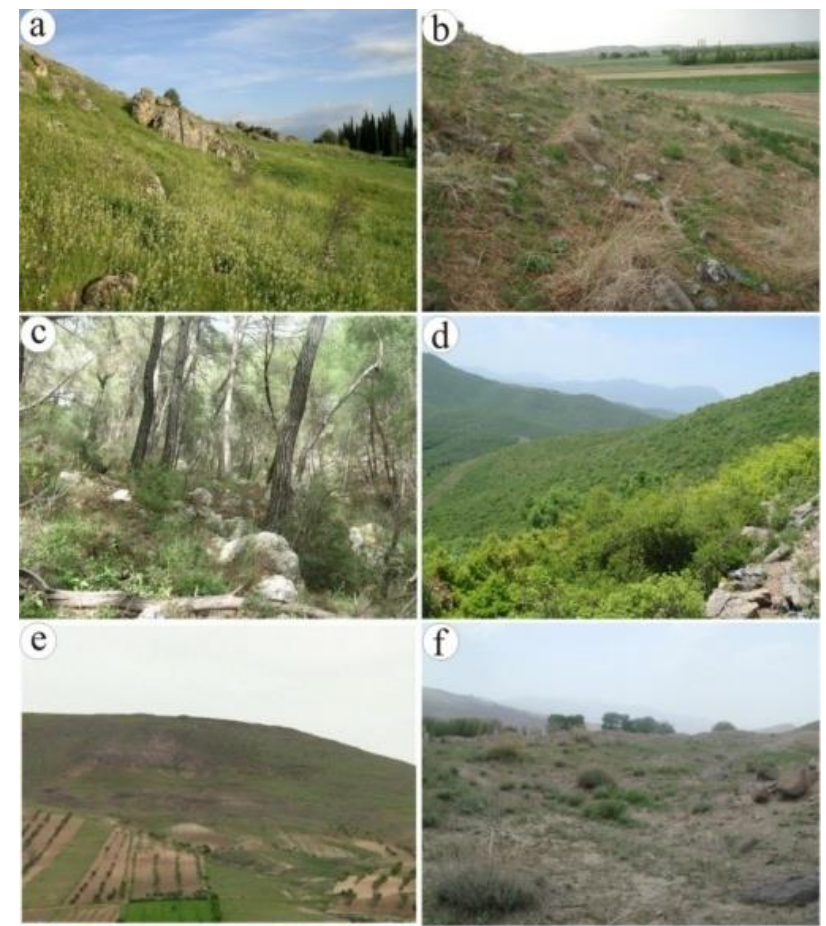

e
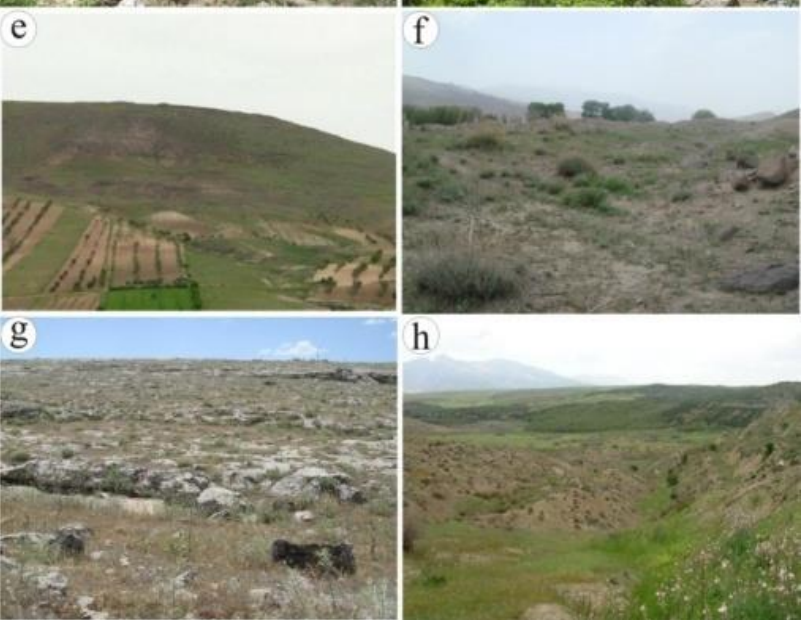

h

Figure 4: General views of the different biotopes from Anatolia and Cyprus where the specimens were collected. a) Pamukkale (Denizli), April-2011; b) Yağmapınar (Konya), May-2012; c) Mut (Mersin), April-2011; d) Hasanbeyli (Osmaniye), May-2012; e) Küplüce (Kilis), April-2007; f) Yukarı Çığrıklı village (Kars), May2012; g) Savaşan village (Şanlıurfa), May-2012; h) Gönyeli (Cyprus), April-2007.

According to the obtained data from the examined specimens, Xerotyphlops vermicularis can be described as: a slender snake rather like an earthworm; head inconspicuous, not distinct from neck and not easily distinguishable from the tail; eyes underneath scales, visible as two small black dots; snout is rounded; mouth subterminal; no enlarged ventral scales; very short tail as wide as long $(\mathrm{TL} / \mathrm{TD}=1.17 \pm 0.22$ and $1.20 \pm 0.24$ in Anatolia and Cyprus, respectively), with a small spine at tip; body covered with smooth scales of uniform size. The widest 
plate on the head is rostral not reaching level of ocular shield (DRE: $0.21 \mathrm{~mm}$ and $0.34 \mathrm{~mm}$ in Anatolia and Cyprus) (except one specimen from Anatolia), it is in contact with nasals and $1^{\text {st }}$ supralabials; rostral, preocular, $1^{\text {st }}$ and $2^{\text {nd }}$ supralabial in contact with nasals incompletely divided, nasal cleft proceeding from second supralabial (Fig. 2); as wide as half of the depth preocular (PW/PD: 0.57 and 0.53 in Anatolia and Cyprus) and ocular plate (OW/OD: 0.58 and 0.57 in Anatolia and Cyprus), Oculare is slightly greater than preocular (PW/OW: 0.91 and 0.85, PD/OD: 0.93 and 0.92 in Anatolia in Cyprus), Preoculare is in contact with nasal, ocular and $2^{\text {nd }}$ supralabiale, ocular also is in contact with preocular, $3^{\text {rd }}$ and $4^{\text {th }}$ supralabial; 4 supralabials, 4-3-2-1 from largest to smallest; 4 infralabials. The meristic and metric characters obtained from our materials of Xerotyphlops vermicularis in Anatolia and Cyprus were summarized in Table 1 and 2.
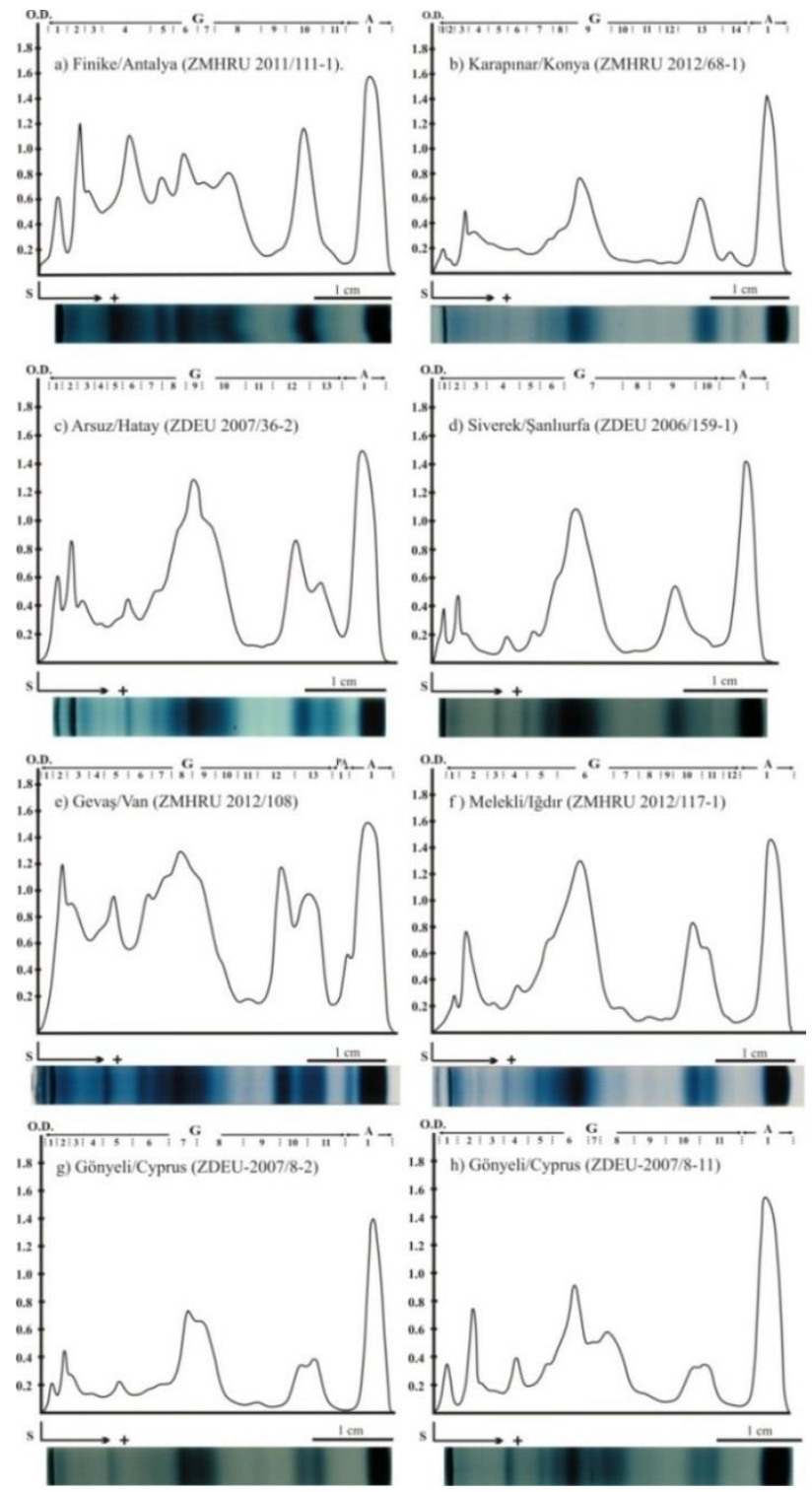

Figure 5: Electropherograms representing the electrophoretical separations of blood-serum proteins in Anatolia (a-f) and Cyprus (g-h), together with their corresponding densitometric curves (OD: optical density, S: start -the border between the stacking and separation gels- , G: globulins zone, PO: Postalbumin zone, A: albumin-like proteins zone). All electopherograms used here are selected from those of adults.
Table 1: Some meristic characters of the Xerotyphlops vermicularis. $\mathrm{N}$ : number of specimens; SD: Standard deviation; the other abbreviations of characters were given in Material and Methods.

\begin{tabular}{lcccc}
\cline { 2 - 5 } & \multicolumn{2}{c}{ Anatolia $(\mathbf{n}=\mathbf{2 7 3})$} & \multicolumn{2}{c}{ Cyprus $(\mathbf{n}=76)$} \\
& Mean \pm SD & Range & Mean \pm SD & Range \\
\cline { 2 - 5 } MBS & $22.34 \pm 0.80$ & $20-24$ & $22.78 \pm 0.86$ & $22-24$ \\
MTS & $18.91 \pm 1.14$ & $17-22$ & $11.80 \pm 0.85$ & $10-13$ \\
DC & $11.86 \pm 0.75$ & $10-15$ & $20.83 \pm 1.02$ & $18-22$ \\
SC & $10.15 \pm 1.18$ & $4-12$ & $10.84 \pm 0.95$ & $10-12$ \\
MDS & $387.79 \pm 20.10$ & $307-433$ & $411.37 \pm 16.04$ & $365-443$ \\
\hline
\end{tabular}
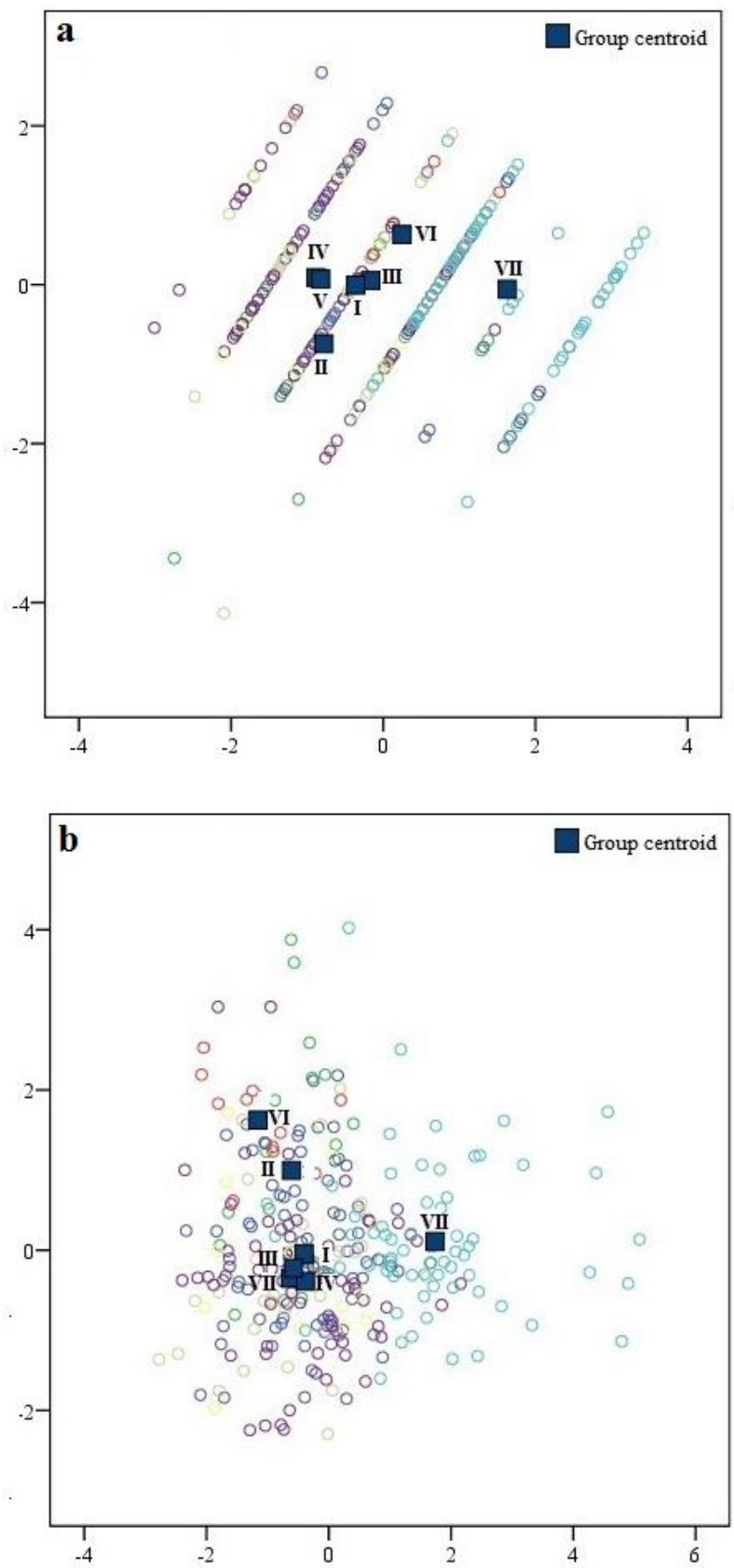

Figure 6: Representation of the first two canonical functions from discriminant analysis performed on meristic characters (a) and percra index values (b) of the seven groups of Anatolian and Cyprian populations. 
The number of supralabials is 4 in the Anatolian and Cyprian specimens as mentioned above. This value shows similarity to the previous results Boulenger (1893); Başoğlu and Baran (1980); Baran and Atatür (1998); Atatür and Göçmen (2001); Franzen et al. (2008); Afroosheh et al. (2013); Afsar et al. (2016). This character is given as 2 (Arıkan et al. 2000; Kumlutaş et al. 2004) or 3 (Afşar and Tok, 2011). These differences could be explained by counting style of the different researchers.

Table 2: Some mensural characters (in $\mathrm{mm}$ ) of the specimens of Xerotyphlops vermicularis. 1: Values in raw data; 2 : Index values in PERCRA (percentages of rostrum-anus length: [each metric character/RA] $\times 100$ ), according to Werner (1971). N: number of specimens; SD: Standard deviation, the other abbreviations of characters were given in Material and Method.

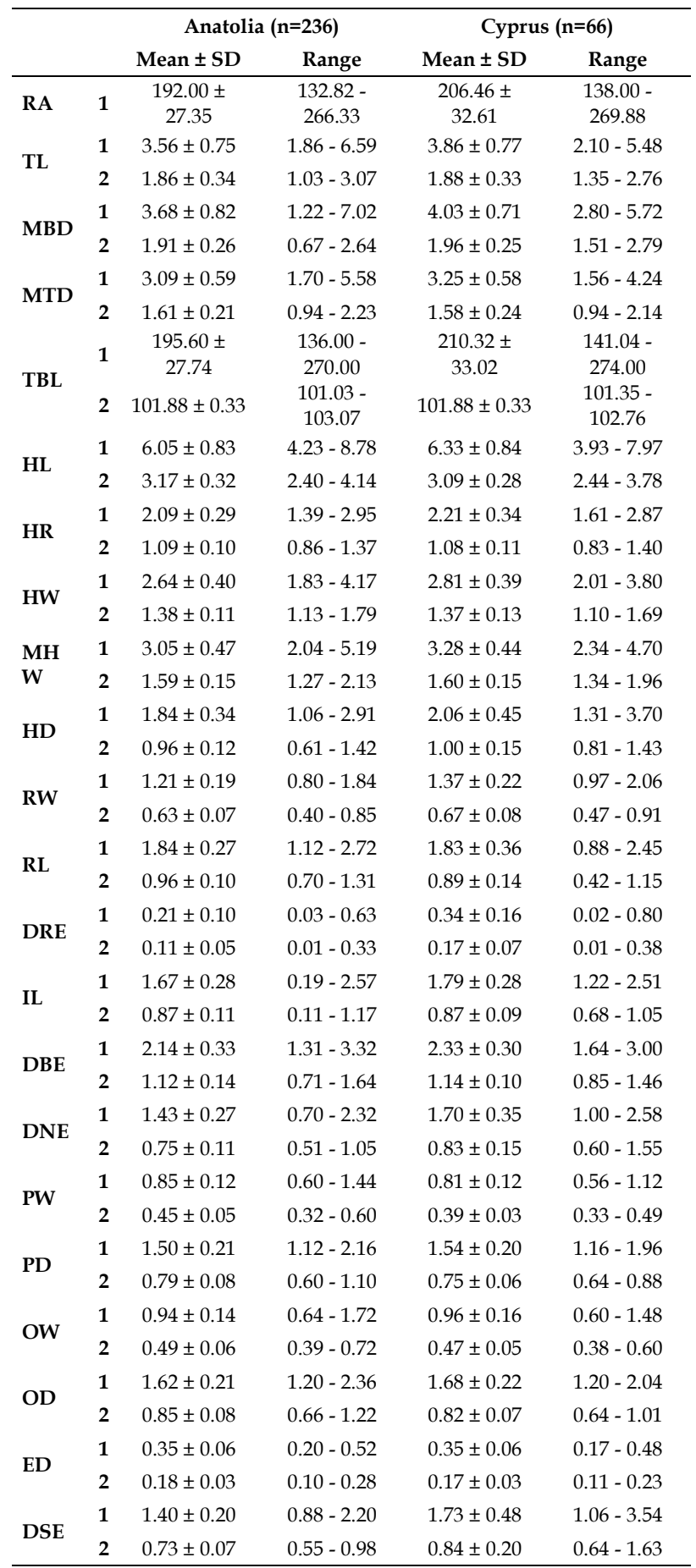

As a result of the comparison of seven groups according to the meristic characters, the first one out of the formed functions explained $94.11 \%$ of the total variance and $p$ values that test the importance of functions were also significant (Table 3). At the same time, 7 groups were correctly classified as $33.1 \%$ in the analysis. Also, as a result of the PERCRA index values and metric characters, the second one out of the formed functions explained $84.88 \%$ (for PERCRA index values) and $80.67 \%$ (for metric characters) of the total variance, and $p$ values that test the importance of functions are also important (Table 3). At the same time, 7 groups were correctly classified as $42.7 \%$ (for PERCRA index values) and $46.8 \%$ (for meristic characters) in the analysis.

In the last step (stepwise method) of the discriminant analysis, the best characters distinguishing the groups were determined as MTS and MDS (for meristic characters); HL, RW, DRE, PW, PD and DSE (for PERCRA index values and metric characters). Descriptive statistics for the characters mentioned above including the six groups of Anatolian populations were summarized in Table 4 and 5. Also Cyprian population was given in Table 1 and 2.

As a result of the statistical analysis of the meristic characters among the populations, the six groups belonging to the population of Anatolia are partially divided into three populations. Although they are divided into three populations, they are close to each other (Fig. 6a). Considering all groups; Group I, III, IV and V form a subgroup, Grup II and VI separate subgroups. Considering the value ranges of the groups, this distinction is due to the wide range of MDS characters. In addition, in Group I, III, IV and V the mean values are close while in Group II and VI these values are low and high respectively. Cyprian population (Group VII) is clearly distinguished from these groups. This difference among groups is due to the significant differences in MDS characters.

Regarding all the meristic characters, based on the Student T-test, four meristic characters [mid-tail scales (MTS), dorsocaudals (DC), subcaudals, (SC) and middorsal scales (MDS)] were significantly different between the two populations $(\mathrm{p} \leq 0.05)$. The means of other characters except dorsocaudals (DC) were higher in Cyprian population (Table 2). When the values of the dorsocaudals (DC), the subcaudals (SC), and middorsal scales (MDS) are considered, it seems they overlap; thus, this character may have a wide range of variation. Additionally, these values show similarity to the previous studies [Boulenger (1893); Mehely (1894); Reed and Marx (1959); Helmich (1962); Başoğlu and Baran (1980); Baran (1982); Disi (1985); Osenegg (1989); Leviton et al. (1992); Baran and Atatür (1998); Arıkan et al. (2000); Atatür and Göçmen (2001); Kumlutaş et al., (2004); Franzen et al.(2008); Göçmen et al. (2009); Afsar and Tok (2011); Afroosheh et al.(2013); Afsar et al. (2016)]. The same situation is not valid for the mid-tail scales (MTS). In Anatolia, MTS is 17-(18.91)-22. It ranges between 17-19 on 190 specimens (\%69.60) and $20-22$ on 83 specimens (\%30.40). Also in Cyprus, MTS is 17-(20.83)-22. It ranges 20-22 on 74 specimens (\%97.36) and 18-19 on 2 specimens (\%2.64). When this character (MTS) is considered, it shows a significant taxonomical difference between the Anatolian and Cyprian populations. 
As a result of the statistical analyses conducted among the populations with metric characters and PERCRA index values of the samples examined, it is seen that Cyprus populations are clearly separated from Anatolian populations in terms of their head structure. In this case, it is understood that the main difference among groups is in the head structure. Considering all groups; Group I, III, IV and V form a subgroup, Group II and VI form a subgroup (Fig. 6b). Cyprian population (Group VII) is clearly distinguished from these groups. As a result, six groups of the Anatolian population are divided into two subgroups. Moreover, it is seen that Cyprus population (Group VII) is largely separated from the Anatolian populations. Cyprian population has higher average values than the Anatolian populations which results in a distinction of this group.

Table 3: Discriminant analysis results of meristic characters (a), metric characters (b), and percra index values (c) of groups.

\begin{tabular}{|c|c|c|c|c|c|c|c|c|c|}
\hline & 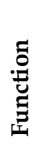 & 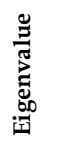 & 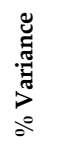 & 。 & 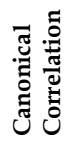 & 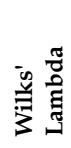 & $\tilde{z}$ & t & 2 \\
\hline \multirow{2}{*}{ a } & 1 & 0,89 & 94,11 & 94,11 & 0,69 & 0,50 & 198,53 & 12,00 & 0,000 \\
\hline & 2 & 0,06 & 5,89 & 100,00 & 0,23 & 0,95 & 15,58 & 5,00 & 0,008 \\
\hline \multirow{6}{*}{ b } & 1 & 0,91 & 64,66 & 64,66 & 0,69 & 0,33 & 309,43 & 48,00 & 0,000 \\
\hline & 2 & 0,23 & 16,01 & 80,67 & 0,43 & 0,63 & 128,66 & 35,00 & 0,000 \\
\hline & 3 & 0,16 & 11,19 & 91,86 & 0,37 & 0,77 & 71,91 & 24,00 & 0,000 \\
\hline & 4 & 0,08 & 5,42 & 97,29 & 0,27 & 0,89 & 31,06 & 15,00 & 0,009 \\
\hline & 5 & 0,03 & 2,32 & 99,61 & 0,18 & 0,96 & 10,51 & 8,00 & 0,231 \\
\hline & 6 & 0,01 & 0,39 & 100,00 & 0,07 & 0,99 & 1,53 & 3,00 & 0,676 \\
\hline & 1 & 0,98 & 71,79 & 71,79 & 0,70 & 0,35 & 298,75 & 42,00 & 0,000 \\
\hline & 2 & 0,18 & 13,09 & 84,88 & 0,39 & 0,70 & 103,50 & 30,00 & 0,000 \\
\hline & 3 & 0,12 & 8,83 & 93,71 & 0,33 & 0,82 & 56,46 & 20,00 & 0,000 \\
\hline & 4 & 0,07 & 5,06 & 98,77 & 0,25 & 0,92 & 23,90 & 12,00 & 0,021 \\
\hline & 5 & 0,01 & 0,89 & 99,66 & 0,11 & 0,98 & 4,79 & 6,00 & 0,571 \\
\hline & 6 & 0,00 & 0,34 & 100,00 & 0,07 & 1,00 & 1,34 & 2,00 & 0,511 \\
\hline
\end{tabular}

According to the data obtained from the examined specimens, the body properties and shape, the total body length, tail length, the body diameter, and the eye diameter show similarity to the information given by Boulenger (1893); Werner (1919); Terent'ev and Chernov (1949); Reed and Marx (1959); Helmich (1962); Haas and Werner (1969); Baran (1976); Başoğlu and Baran (1980); Baran (1982); Disi (1985); Osenegg (1989); Leviton, Anderson, Adler and Minton (1992); Baran and Atatür (1998); Arıkan, Tok, Çevik, and Olgun (2000); Atatür and Göçmen (2001); Kumlutaş et al. (2004); Franzen, Bußmann, Kordges and Thiesmeier (2008); Göçmen et al. (2009); Afsar and Tok (2011); Afroosheh et al. (2013); Afsar et al. (2016).

By the averages of the rostrum-anus length, the head radius, the head width, and the head depth Cyprian population are larger than the Anatolian population. This is confirmed by the statistical analysis (Table 1). These differences could be the result of the geographical variations that are seen in the species associated to the local ecology. According to the Student T-test between two populations (Anatolian and Cyprian), some of the raw data and PERCRA (Werner, 1971) index values of the following metric characters [the head length (HL), therostral width (RW), the distance from anterior of rostrale to eye level (DRE), the distance from anterior of nostril to posterior of eye (DNE), the preocular width $(\mathrm{PW})$, and the ocular depth (OD)] indicated differences $(\mathrm{p} \leq 0.05)$. A significant taxonomical difference existed between the Anatolian and Cyprian populations regarding the abovementioned characteristics.

In terms of coloration, no difference has been observed in color between adults and juvenile specimens of Xerotyphlops vermicularis in the Anatolian and Cyprian populations. Only, in some juvenile specimens, it was observed that the coloring of the body is a bit darker when compared with the adults. Therefore, adults and juveniles were assessed together. The dorsum color of $X$. vermicularis is flesh (Fig. 7a and 7f) or brown [a bit light (Fig. $7 \mathrm{~b}$ and $7 \mathrm{c}$ ) or dark (Fig. $7 \mathrm{~d}$ and $7 \mathrm{e}$ )] in some individuals. The dorsal and ventral regions are separated by an obvious border from each other in individuals with brown coloration. But, this condition is not present in individuals with flesh coloration. The rostral coloration is present in some individuals with brown dorsum color (Fig. $8 \mathrm{~b}$ and $8 \mathrm{c}$ ), but not in flesh coloration specimens (Fig. $8 \mathrm{a})$. From the head to the end of tail, the dorsal ground color is darker. Posterior part of dorsal scales is distinctly darker than anterior part in individuals with brown coloration. But, this condition is not present in individuals with flesh coloration. Lastly, ventrum is generally yellowish-white in color and is spotless in all specimens. The situation of the dorsal coloration, to be flesh or brown, is not dependent on the age.

Schmidtler and Bischoff (1995) suggested that these kinds of differences could be a reason for dividing into sub-species and basalt-limestone ground could be a reason why Apathya cappadocica population on the east of Euphrates divided into two subspecies as Apathya cappadocica schmidtlerorum (in volcanic areas) and A. c. muhtari (in karstic regions). Additionally, the color of the ground could be a reason for dorsal coloration which is a sub-species character. But, the dorsum color variations that were explained in this study and the situation of the rostral coloration (none or present) are not dependent on body size. Moreover, it is regarded as a variation related to the geographical variations which are seen in the species in interaction with the local ecology.

\subsection{Geometric Morphometric Analyses}

There are no geometric morphometric studies for Xerotyphlops vermicularis. Head shapes are shown by using 15 landmarks that are determined by the researchers of this study in dorsal view of head. Thus, the affinity, similarities, and differences between the 7 groups determined were investigated. With geometric morphometric analyses, the similarities or differences in the classical morphology studies among the groups were tried to be supported.

209 adult specimens which belong to Xerotyphlops vermicularis were analyzed. After placing the landmarks in TPSDIG.12 (Rohlf, 2008), the adequacy of the number of landmarks used was tested in TPSSUPER 1.14 (Rohlf, 2004). After receiving confirmatory results from this program, Procrustes was performed to determine the distribution of the landmarks and to detect if there was any deviation in distribution (Fig. 9). Xerotyphlops vermicularis 
were regarded as seven groups for the grouping necessity to perform PCA and CVA. In PCAGen6p, IMP (Zelditch et al., 2007) the distribution of individuals along the 1st and 2nd (PC1 and PC2), on the 2nd and 3rd (PC2 and PC3), and on the 1st and 3rd (PC1 and PC3) principal components were examined (Fig. 10). The relative warps were determined in TPSRELW (Rohlf, 2007). According to the results, the landmarks having the highest relative scores were found to be the 10th and 14th, while the landmark having the lowest relative scores was found to be the 4 th and 5 th. Results concerning the value of variance showed that the values $S^{2}=0.00045702, S^{2}=0.00041384$, and $S^{2}=$ 0.00040368 - referring to landmarks number 4,5 , and 15 respectively. CVAGen6p, IMP analysis was conducted to determine if there was any significant difference between the groups. MANOVA was conducted in the same program and; according to the values obtained, it was concluded that all 7 groups were insignificantly different from each other (Table 6).
CANOVAR was conducted in CVAGen6n, IMP and the distribution of individuals on the 1st two canonical variants were determined (Fig. 11).

The mean values were obtained from the tps values by using the Morpheus software. These mean values were then grouped in NTYSYS using SAHN tree. A dissimilarity tree was then constructed using unweight pair group method with arithmetic mean (UPGMA) (Fig. 12).

According to the results of the analysis (PCA and CVA analysis), it was determined that the six groups on the Anatolian population formed a cluster and the Cyprus population formed a separate cluster. In addition, while the Cyprus population is distinct from other groups, it can be concluded that the Group I may be a transition population between the other groups and Cyprus population. Results from the UPGMA tree confirm the PCA and CVA data.

Table 4: Some meristic characters of groups in Anatolia populations. N: number of specimens; SD: Standard deviation; the other abbreviations of characters were given in Material and Method.

\begin{tabular}{|c|c|c|c|c|c|c|c|c|c|c|c|c|}
\hline & \multicolumn{2}{|c|}{ Group I (n=98) } & \multicolumn{2}{|c|}{ Group II (n=20) } & \multicolumn{2}{|c|}{ Group III (n=49) } & \multicolumn{2}{|c|}{ Group IV $(n=79)$} & \multicolumn{2}{|c|}{ Group V $(n=14)$} & \multicolumn{2}{|c|}{ Group VI (n=13) } \\
\hline & $\begin{array}{l}\text { Mean } \\
\pm \text { SD }\end{array}$ & Range & $\begin{array}{l}\text { Mean } \\
\pm S D\end{array}$ & Range & $\begin{array}{l}\text { Mean } \\
\pm \text { SD }\end{array}$ & Range & $\begin{array}{l}\text { Mean } \\
\pm \text { SD }\end{array}$ & Range & $\begin{array}{l}\text { Mean } \\
\pm \text { SD }\end{array}$ & Range & $\begin{array}{l}\text { Mean } \\
\pm \text { SD }\end{array}$ & Range \\
\hline MTS & $\begin{array}{l}19,19 \\
\pm 1,28\end{array}$ & $17-22$ & $\begin{array}{l}19,15 \\
\pm 0,99\end{array}$ & $18-21$ & $\begin{array}{c}19,05 \\
\pm 0,96\end{array}$ & $17-20$ & $\begin{array}{c}18,47 \\
\pm 0,98\end{array}$ & $17-21$ & $\begin{array}{c}18,57 \\
\pm 0,94\end{array}$ & $17-20$ & $\begin{array}{c}18,92 \\
\pm 1,12\end{array}$ & $17-20$ \\
\hline MDS & $\begin{array}{r}391,38 \\
\pm 17,23\end{array}$ & $357-433$ & $\begin{array}{r}373,60 \\
\pm 22,79\end{array}$ & $310-403$ & $\begin{array}{r}388,93 \\
\pm 25,73\end{array}$ & $307-433$ & $\begin{array}{r}383,87 \\
\pm 18,07\end{array}$ & $351-417$ & $\begin{array}{r}385,43 \\
\pm 16,70\end{array}$ & $356-413$ & $\begin{array}{r}405,38 \\
\pm 13,04\end{array}$ & $389-429$ \\
\hline
\end{tabular}

Table 5: Some mensural characters (in $\mathrm{mm}$ ) of the specimens of groups in Anatolia populations. 1: Values in raw data; 2: Index values in PERCRA (percentages of rostrum-anus length: [each metric character/RA] × 100), according to Werner (1971). N: number of specimens; SD: Standard deviation, the other abbreviations of characters were given in Material and Method.

\begin{tabular}{|c|c|c|c|c|c|c|c|}
\hline & & \multicolumn{2}{|c|}{ Group I (n=82) } & \multicolumn{2}{|c|}{ Group II (n=19) } & \multicolumn{2}{|c|}{ Group III $(n=45)$} \\
\hline & & Mean \pm SD & Range & Mean \pm SD & Range & Mean \pm SD & Range \\
\hline \multirow{2}{*}{ HL } & 1 & $6.14 \pm 0.82$ & $4.46-8.43$ & $5.96 \pm 0.69$ & $4.78-7.18$ & $6.34 \pm 0.93$ & $4.78-8.57$ \\
\hline & 2 & $3.23 \pm 0.32$ & $2.54-4.02$ & $2.97 \pm 0.26$ & $2.48-3.50$ & $3.23 \pm 0.31$ & $2.83-4.14$ \\
\hline \multirow{2}{*}{ RW } & 1 & $1.26 \pm 0.17$ & $0.80-1.68$ & $1.25 \pm 0.15$ & $1.00-1.60$ & $1.22 \pm 0.21$ & $0.89-1.60$ \\
\hline & 2 & $0.66 \pm 0.08$ & $0.40-0.85$ & $0.63 \pm 0.07$ & $0.48-0.81$ & $0.62 \pm 0.06$ & $0.53-0.75$ \\
\hline \multirow{2}{*}{ DRE } & 1 & $0.23 \pm 0.09$ & $0.04-0.52$ & $0.20 \pm 0.09$ & $0.08-040$ & $0.18 \pm 0.09$ & $0.03-0.47$ \\
\hline & 2 & $0.12 \pm 0.05$ & $0.03-0.26$ & $0.10 \pm 0.04$ & $0.04-020$ & $0.09 \pm 0.05$ & $0.00-0.31$ \\
\hline \multirow{2}{*}{ PW } & 1 & $0.86 \pm 0.11$ & $0.68-1.28$ & $0.87 \pm 0.10$ & $0.68-1.08$ & $0.87 \pm 0.14$ & $0.68-1.20$ \\
\hline & 2 & $0.45 \pm 0.05$ & $0.36-0.57$ & $0.43 \pm 0.06$ & $0.37-0.60$ & $0.44 \pm 0.04$ & $0.36-0.55$ \\
\hline \multirow{2}{*}{ PD } & 1 & $1.53 \pm 0.18$ & $1.12-2.04$ & $1.65 \pm 0.22$ & $1.24-2.04$ & $1.54 \pm 0.22$ & $1.20-2.04$ \\
\hline & 2 & $0.8 \pm 0.07$ & $0.68-1.02$ & $0.82 \pm 0.10$ & $0.65-1.10$ & $0.78 \pm 0.06$ & $0.70-0.90$ \\
\hline \multirow{2}{*}{ DSE } & 1 & $1.40 \pm 0.18$ & $1.08-1.84$ & $1.41 \pm 0.17$ & $1.03-1.80$ & $1.44 \pm 0.24$ & $0.88-2.00$ \\
\hline & 2 & $0.74 \pm 0.08$ & $0.57-0.94$ & $0.71 \pm 0.09$ & $0.55-0.98$ & $0.73 \pm 0.07$ & $0.57-0.85$ \\
\hline
\end{tabular}

\begin{tabular}{|c|c|c|c|c|c|c|c|}
\hline & & \multicolumn{2}{|c|}{ Group IV $(n=65)$} & \multicolumn{2}{|c|}{ Group V $(n=14)$} & \multicolumn{2}{|c|}{ Group VI $(n=11)$} \\
\hline & & Mean \pm SD & Range & Mean \pm SD & Range & Mean \pm SD & Range \\
\hline \multirow{2}{*}{ HL } & 1 & $5.88 \pm 0.86$ & $4.23-8.78$ & $6.01 \pm 0.63$ & $4.78-6.77$ & $5.73 \pm 0.48$ & $4.99-6.51$ \\
\hline & 2 & $3.17 \pm 0.30$ & $2.40-3.91$ & $3.27 \pm 0.28$ & $2.88-3.81$ & $2.80 \pm 0.24$ & $2.41-3.07$ \\
\hline \multirow{2}{*}{ RW } & 1 & $1.13 \pm 0.19$ & $0.84-1.84$ & $1.18 \pm 0.15$ & $0.97-1.52$ & $1.27 \pm 0.16$ & $1.08-1.60$ \\
\hline & 2 & $0.61 \pm 0.06$ & $0.47-0.85$ & $0.64 \pm 0.05$ & $0.55-0.73$ & $0.61 \pm 0.04$ & $0.52-0.66$ \\
\hline \multirow{2}{*}{ DRE } & 1 & $0.21 \pm 0.10$ & $0.04-0.63$ & $0.24 \pm 0.12$ & $0.10-0.52$ & $0.18 \pm 0.06$ & $0.08-0.24$ \\
\hline & 2 & $0.11 \pm 0.05$ & $0.02-0.33$ & $0.13 \pm 0.06$ & $0.06-0.27$ & $0.09 \pm 0.04$ & $0.04-0.14$ \\
\hline \multirow{2}{*}{ PW } & 1 & $0.81 \pm 0.13$ & $0.60-1.44$ & $0.86 \pm 0.10$ & $0.80-1.16$ & $0.95 \pm 0.10$ & $0.80-1.16$ \\
\hline & 2 & $0.44 \pm 0.04$ & $0.32-0.55$ & $0.47 \pm 0.07$ & $0.40-0.59$ & $0.46 \pm 0.04$ & $0.40-0.53$ \\
\hline \multirow{2}{*}{ PD } & 1 & $1.41 \pm 0.22$ & $1.16-2.16$ & $1.45 \pm 0.20$ & $1.12-1.84$ & $1.60 \pm 0.11$ & $1.40-1.76$ \\
\hline & 2 & $0.76 \pm 0.07$ & $0.60-1.01$ & $0.79 \pm 0.07$ & $0.67-0.97$ & $0.78 \pm 0.07$ & $0.68-0.89$ \\
\hline \multirow{2}{*}{ DSE } & 1 & $1.36 \pm 0.23$ & $1.03-2.20$ & $1.40 \pm 0.19$ & $1.08-1.75$ & $1.48 \pm 0.19$ & $1.20-1.80$ \\
\hline & 2 & $0.73 \pm 0.07$ & $0.59-0.94$ & $0.76 \pm 0.07$ & $0.69-0.94$ & $0.72 \pm 0.04$ & $0.65-0.80$ \\
\hline
\end{tabular}


Table 6: MANOVA table of seven groups.

\begin{tabular}{lccc}
\hline & Lambda & chi $^{2}$ & p values \\
\hline Axis 1 & 0,0906 & 459,818 & $\mathrm{p}<2,22045 \mathrm{E}-016$ \\
Axis 2 & 0,2977 & 232,037 & $\mathrm{p}=2,00046 \mathrm{E}-008$ \\
Axis 3 & 0,4356 & 159,137 & $\mathrm{p}=5,46081 \mathrm{E}-005$ \\
Axis 4 & 0,5757 & 105,738 & $\mathrm{p}=2,94681 \mathrm{E}-003$ \\
\hline
\end{tabular}

\section{Conclusion}

There were significant differences between Xerotyphlops vermicularis populations from Anatolia and Cyprus, regarding their pholidotic characters, metric measurements, and geometric morphometrics. Therefore, it is suggested that the Cyprian populations could properly be named as a different taxon.
Acknowledgements: The study was produced from the $\mathrm{PhD}$ thesis of the first author and supervised by the second author. The second author, Prof. Dr. Bayram GÖÇMEN, passed away on 22 March 2019. Since I started my academic life in 2006, I would like to express my gratitude to Prof. Dr. Bayram GÖÇMEN who was beside me with his knowledge and experience, and did not spare its financial and moral support. We would like to express our appreciation to the Ege University Scientific Research Project Commission that supported this study as a Project (No: 2010-Fen057) and also we are grateful to Assoc. Prof. Dr. Mehmet Zülfü YILDIZ (Faculty of Arts and Sciences, Department of Biology, Zoology Section, Adiyaman University, Adiyaman, Turkey) and Dr Deniz Yalçınkaya (Vocational School Department of Medical Services and Techniques, Toros University, Mersin, Turkey) for their assistance during our trips. At the same time, we wish to thank Pinar BARKAN (Morphometry Laboratory, Department of Biology, Faculty of Science, Hacettepe University, Ankara, Turkey) for geometric morphometric studies.
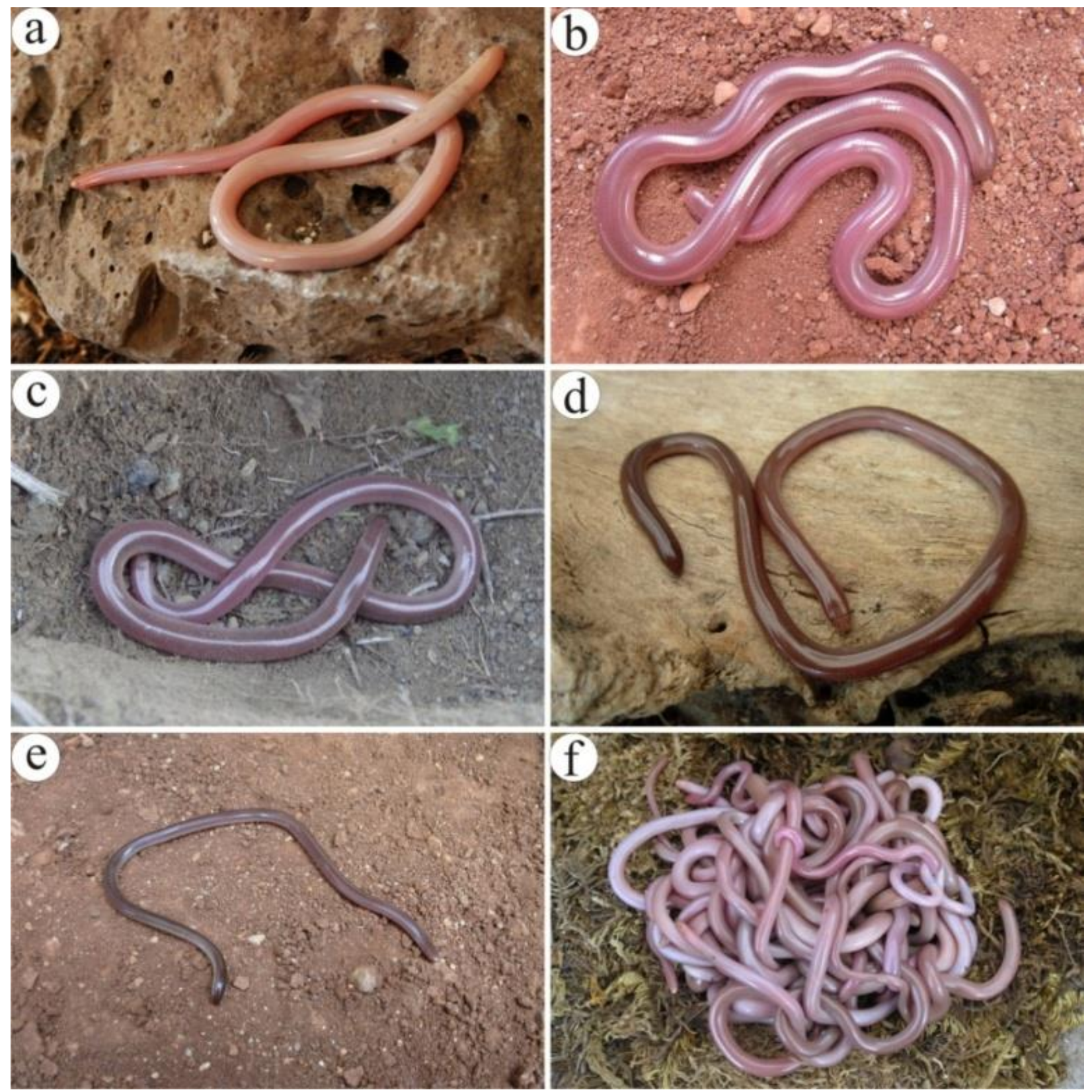

Figure 7: The general views of specimens from different populations of Xerotyphlops vermicularis. a) Mersin, May-2009, B. GÖÇMEN; b) Suruç (Şanlıurfa), May-2011, M. Z. YILDIZ; c) Melekli (Iğdır), May-2012, B. AKMAN; d) Karakeçi (Şanlıurfa), April-2007, B. GÖÇMEN; e) Viranşehir (Şanlıurfa), May-2011, M. Z. YILDIZ, f) Gönyeli (Cyprus), April-2007, B. GÖÇMEN. 

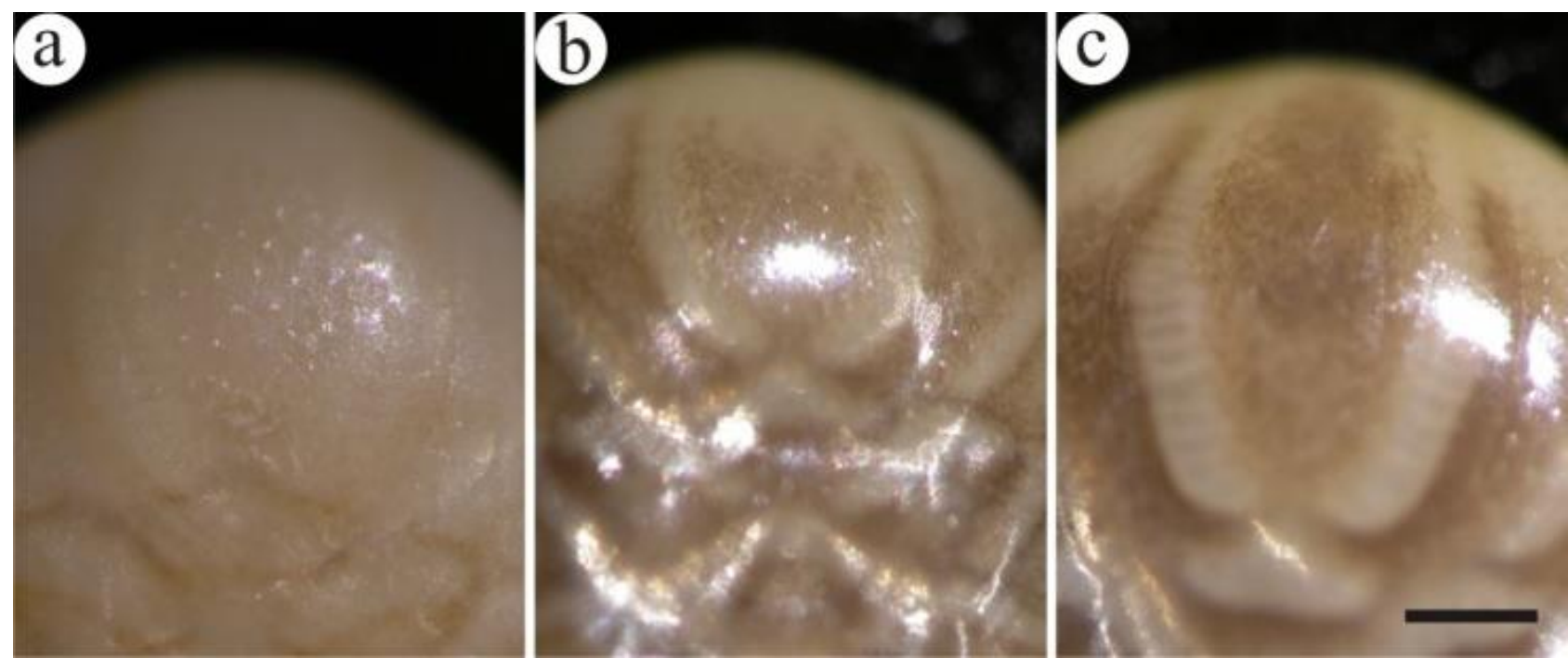

Figure 8: The rostral coloration in the Anatolian and Cyprus populations. (a: ZDEU 2007/137-1, b: ZMADYU 2011/176, c: ZDEU 2011/331) (Scale bar: $0.40 \mathrm{~mm}$ ).

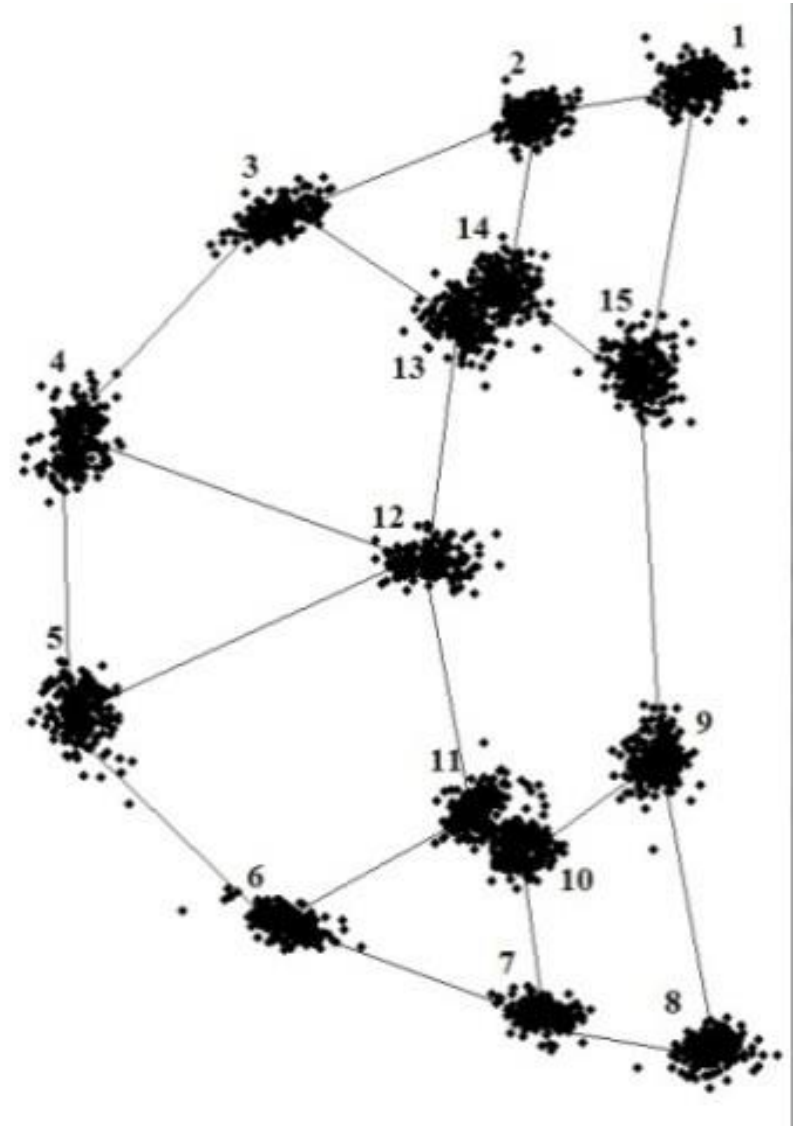

Figure 9: Consensus configuration of the landmarks in females after Procrustes superimposition.

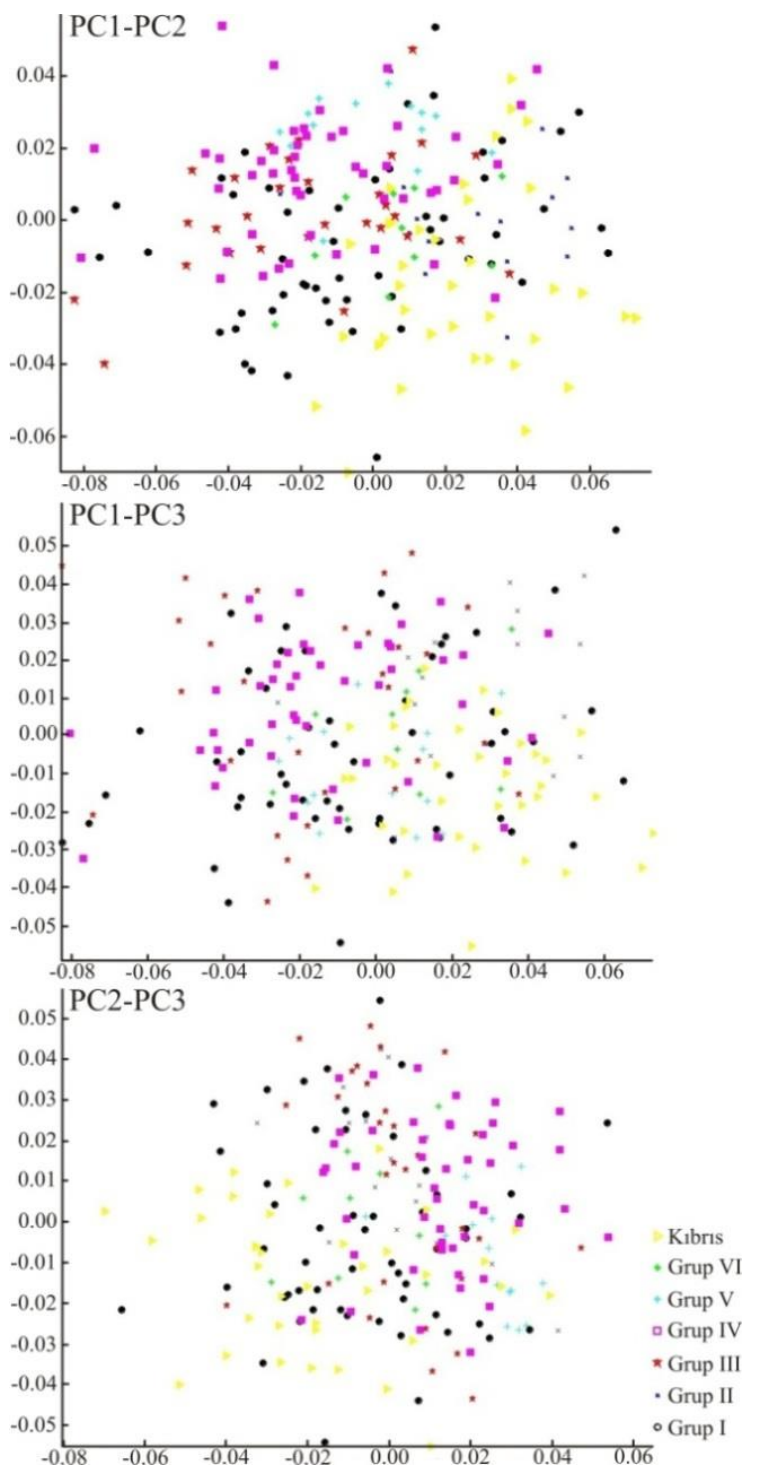

Figure 10: Distribution of individuals along the 1st and 2nd (horizontal axis: PC1, vertical axis: PC2), on the 1st and 3rd (horizontal axis: PC1, vertical axis: PC3) and on the 2nd and 3rd (horizontal axis: PC2, vertical axis: PC3) principal components. 


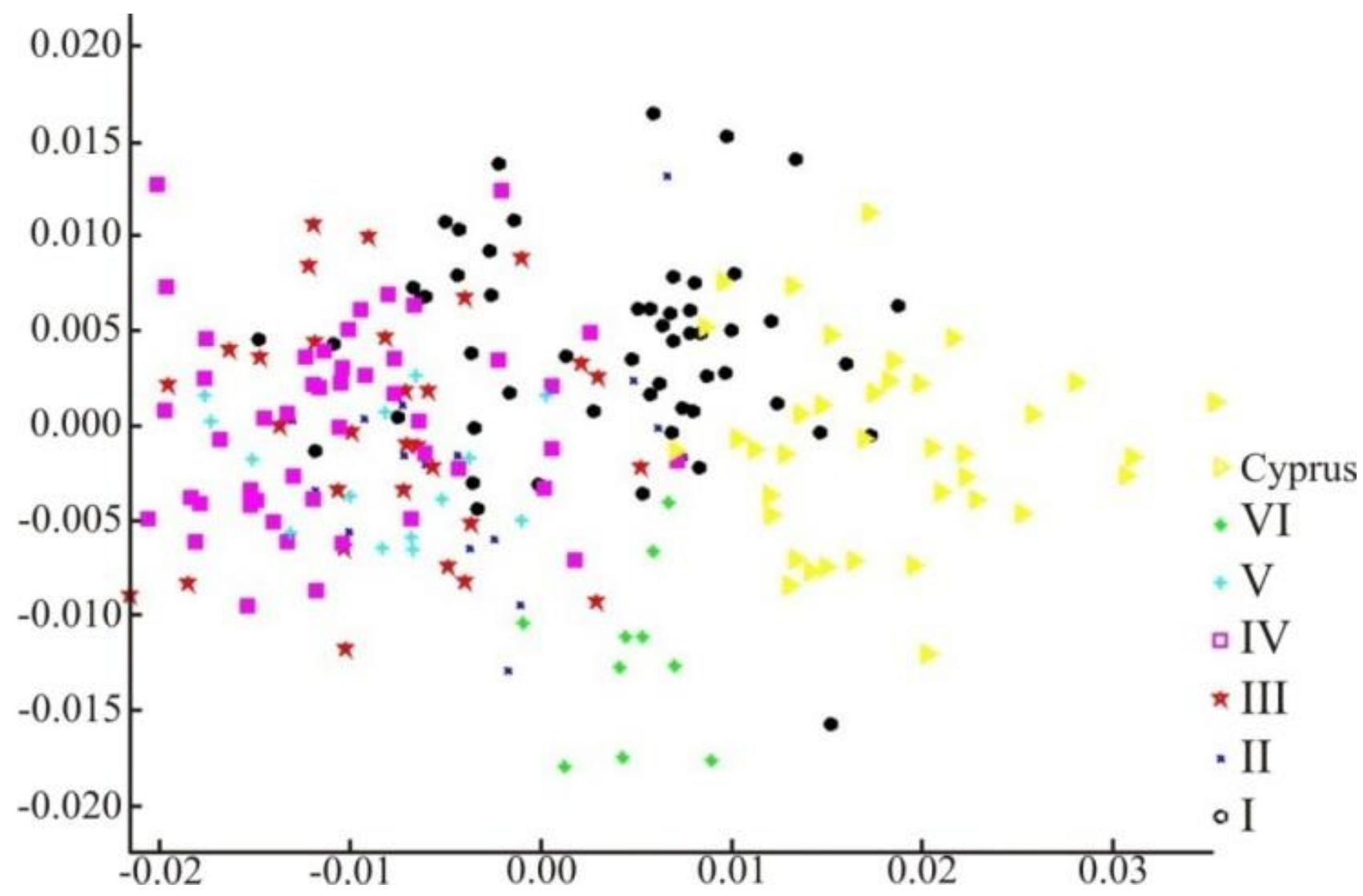

Figure 11: The distribution of groups on the first two canonical variates. Horizontal axis represents CV1, vertical axis represents CV2 and each dot represents one individual.

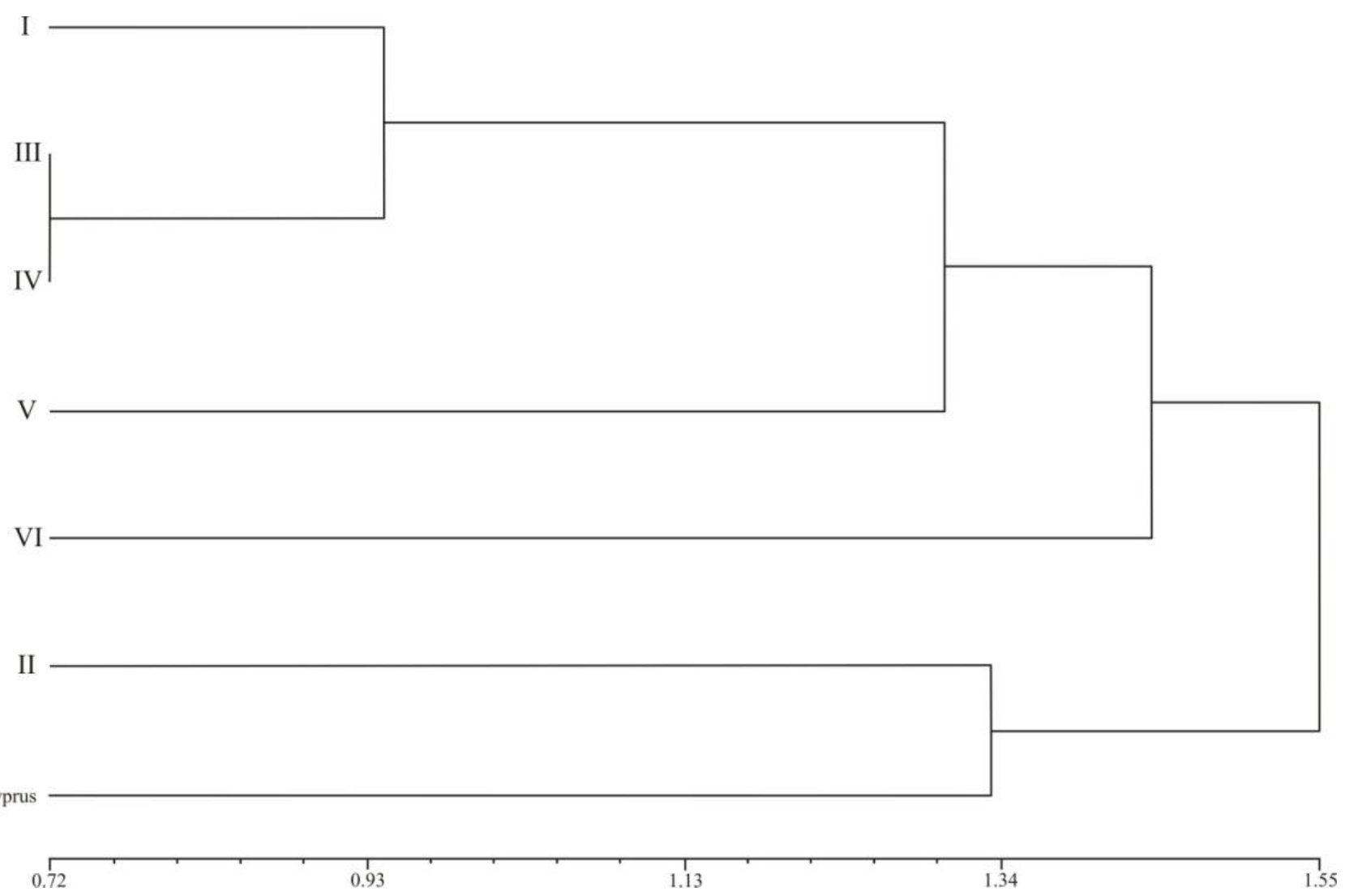

Figure 12: The UPGMA tree that shows the comparison of the 7 groups. 


\section{References}

Adalsteinsson, S.A., Branch, W.R., Trape, S., Vitt, L.J., \& Hedges, S.B. (2009). Molecular Phylogeny, Classification, and Biogeography of Snakes of the Family Leptotyphlopidae (Reptilia, Squamata). Zootaxa, 2244, 1-50.

Afroosheh, M., Rastegar-Pouyani, N., Ghoreishi, S. K., \& Kami, H. G. (2013). Comparison of geographic variations in Typhlops vermicularis (Merrem, 1820) (Ophidia: Typhlopidae) from the Iranian plateau with Turkey and Turkmenistan. Turkish Journal of Zoology, 37, 685-692.

Afsar, M., \& Tok, C.V. (2011). The Herpetofauna of the Sultan Mountains (Afyon-Konya-Isparta) Turkey. Turkish Journal of Zoology, 35(4), 491-501.

Afsar, M., Çiçek, K., Tayhan, Y., \& Tok, C. V. (2016). New records of Eurasian Blind Snake, Xerotyphlops vermicularis (Merrem, 1820) from the Black Sea region of Turkey and its updated distribution. Biharean Biologist, 10(2), 98-103.

Arıkan, H., Tok, C.V., Çevik, İ.E., \& Olgun, K. (2000). 33-36º Boylamlar Arası Orta Torosların Herpetofaunası (Proje No. TBAG-1385 / 195T020). İzmir, Türkiye, 66 pp.

Atatür, M.K., \& Göçmen, B. (2001). Kuzey Kıbrıs'ın Kurbağa ve Sürüngenleri. İzmir, Türkiye, Ege Üniversitesi Basımevi, 63 pp.

Baran, İ., \& Atatür, M.K. (1998). Türkiye Herpetofaunası (Kurbağa ve Sürüngenler). Ankara, Türkiye, T.C. Çevre Bakanlığı, 214 pp.

Baran, İ. (1976). Türkiye Yılanlarının Taksonomik Revizyonu ve Coğrafi Yayılışları. Ankara, Türkiye, TÜBİTAK Yayınları, 177 pp.

Baran, İ. (1981). Kuzey Ege Denizi, Marmara Denizi ve Karadeniz'deki Adalarımızın Herpetofaunasının Taksonomik ve Ekolojik Araştırılması. Doğa Bilim Dergisi, 5, 155-162.

Baran, İ. (1982). Zur Taxonomie Der Schlangen in Südost- und OstAnatolien. Spixiana, 5(1), 51-59 pp.

Barkan, N.P., \& Aytekin, A.M. (2013). Systematical studies on the species of the subgenus Bombus (Thoracobombus) (Hymenoptera: Apidae, Bombus Latreille) in Turkey. Zootaxa, 3737(2), 167-183.

Başoğlu, M., \& Baran, İ. (1980). Türkiye Sürüngenleri, Kısım 2, Yılanlar. İzmir, Türkiye, Ege Üniversitesi Basımevi, 218 pp.

Boulenger, G.A. (1893). Catalogue of the snakes in the British Museum (Natural History). London, England, British Museum of Natural History, $448 \mathrm{pp}$.

Broadley, D.G., \& Wallach, V. (2007). A revision of the genus Leptotyphlops in northeastern Africa and southwestern Arabia (Serpentes: Leptotyphlopidae). Zootaxa, 1408, 1-78.

Budak, A., \& Göçmen, B. (2005). Herpetoloji. İzmir, Türkiye, Ege Üniversitesi Basımevi, 226 pp.

Cox, N., Chanson, J., \& Stuart, S. (2006). The Status and Distribution of Reptiles and Amphibians of the Mediterranean Basin. IUCN, Gland, Switzerland and Cambridge, UK.

Davis, B. J. (1964). Disc Electrophoresis II Method and Application to Human Serum Proteins. Annals of the New York Academy of Sciences, 404427.

Disi, A.M. (1985). A Contribution to the Herpetofauna of Jordan 2. New Records and a Systematic List of Snakes from Jordan. The Snake, 17, 3142.

Esterbauer, H. (1992). Die Herpetofauna Des Östlichhen Golan und Hermongebietes Funde und Bemerkungen Zur Systematik und Ökologie. Zoololgy in the Middle East, 7, 21-54.

Franzen, M., \& Wallach, V. (2002). A New Rhinotyphlops from Southeastern Turkey (Serpentes: Typhlopidae). Journal of Herpetology, 36(2), 176-184.

Franzen, M., Bußmann, M., Kordges, T., \& Thiesmeier, B. (2008). Die Amphibien und Reptilien der Südwest-Türkei. Bielefeld, Germany, Laurenti-Verlag, 328 pp.

Göçmen, B., Atatür, M.K., Budak, A., Bahar, H., Yıldız, M.Z., \& AlpagutKeskin, N. (2009). Taxonomic Notes on the Snakes of Northern Cyprus, with Observations on their Morphologies and Ecologies. Animal biology, 59, 1-29.

Göçmen, B., Nilson, G., Yıldız, M.Z., Arıkan, H., Yalçınkaya, D., \& Akman, B. (2007). On the occurrence of the Black Cat Snake, Telescopus nigriceps (Ahl, 1924) (Serpentes: Colubridae) from the southeastern Anatolia, Turkey with some taxonomical comments. North-Western Journal of Zoology, 3, 81-95.

Greene, H.W. (1997). Snakes: the Evolution of Mystery in Nature. California, USA, Univ of California Press.

Haas, G., \& Werner, Y.L. (1969). Lizards and Snakes from Southwestern Asia, Collected by Henry Field. Bulletin of the Museum of Comparative Zoology, 138(6), 327-405.

Haas, G. (1951). On the Present State of our Knowledge of the Herpetofauna of Paletsine. Bulletin of the Research Council of Israel, 1(3), 67-87.
Hedges, S.B., Marion, A.B., Lipp, K.M., Marin, J., \& Vidal, N. (2014). A taxonomic framework for typhlopid snakes from the Caribbean and other regions (Reptilia, Squamata). Caribbean Herpetology, 49, 1-6.

Helmich, W. (1962). Reptiles and Amphibians of Europe. London, England, Blandford Press, $160 \mathrm{p}$.

Jablonski, D., \& Balej, P. (2015). Xerotyphlops vermicularis (Merrem, 1820), in the west Bulgarian Rhodope Mountains: rediscovery after more than 100 years. Herpetozoa, 27(3/4), 200-203.

Kaliontzopoulou, A., Carretero, M.A., \& Llorente, G.A. (2007). Multivariate and geometric morphometrics in the analysis of sexual dimorphism variation in Podarcis lizards. Journal of Morphology, 268(2), 152-165.

Kornilios, P., Ilgaz, C.., Kumlutaş, Y., Giokas, S., Fraguedakis-Tsolis, S., \& Chondropoulos, B. (2011). The Role of Anatolian Refugia in Herpetofaunal Diversity: an mtDNA Analysis of Typhlops vermicularis Merrem, 1820 (Squamata, Typhlopidae). Amphibia-Reptilia, 32, 351-363.

Kornilios, P., Ilgaz, Ç., Kumlutaş, Y., Lymberakis, P., Moravec, J., Sindaco, R., Rastegar-Pouyani, N., ... \& Chondropoulos, B. (2012). Neogene climatic oscillations shape the biogeography and evolutionary history of the Eurasian blindsnake. Molecular Phylogenetics and Evolution, 62, 856-873.

Kumlutaş, Y., Durmuş, S.H., \& Ilgaz, C.. (2000). Yamanlar Dağı ve Karagöl Civarındaki Kurbağa ve Sürüngenlerin Taksonomisi ve Ekolojisi. Ekoloji, Çevre Dergisi, 37, 12-16.

Kumlutaş, Y., Ȯz, M., Tunc, M.R., Kaska, Y., Ozzdemir, A., \& Düşen, S. (2004). On Snake Species of the Western Taurus Range, Turkey. Natura Croatica, 13(1), 19-33.

Leviton, A.E., Anderson, S.C., Adler, K., \& Minton, S.A. (1992). Handbook to Middle East Amphibians and Reptiles. USA, Ohio, Oxford press, 252 pp.

Mattison, C. (1982). The Care of Reptiles and Amphibians in Captivity. UK, Poole, Blanford Press, 317 pp.

Méhely, L. (1894). Beiträge zur Herpetologie Transkaukasiens und Armeniens (Teil 1+2). Zoologischer Anzeiger, 17, 78-86.

Merrem, B. (1820). Versuch eines Systems der Amphibien: Tentamen systematis amphibiorum. bei Johann Christian Kriege, Marburg, 191 pp.

Mertens, R., \& Wermuth, H. (1960). Die Amphibien und Reptilien Europas. Frankfurt, Germany, Verlag Waldemar Kramer, $252 \mathrm{pp}$.

Moravec, J., Baha El Din, S., Seligmann, H., Naomi, S., \& Werner, Y. L. (1999). Systematics and distribution of the Acanthodactylus pardalis group (Lacertidae) in Egypt and Israel. Zoology in the Middle East 17, 2150 .

Niyomwan, P., Thirakhupt, K., \& Nabhitabhata, J. (2001). A Key to the Blind Snakes in Thailand. Natural History Journal of Chulalongkorn University, $1,47-52$.

Osenegg, K. (1989). Die Amphibien und Reptilien der Insel Zypern (Msc Thesis). University of Bonn, Bonn, Germany.

Özeti, N., \& Atatür, M.K. (1979). A Preliminary survey of the serum proteins of a population of Mertensiella luschani finikensis Başoğlu and Atatür from Finike in Southwestern Anatolia. Istanbul Universitesi Fen Fakültesi Mecmuasi, 44, 23-29.

Pough, F.H., Janis, C.M., \& Heiser, J.B. (1999). Vertebrate Life, 5th ed. USA, New Jersey, Prentice Hall International, 699 pp.

Rage, J.C. (1987). Fossil history. In R.A. Seigel (Ed.), Snakes: Ecology and Evolutionary Biology (pp. 51-76) (Ed.). New York, USA, Macmillan Publishing Company, 529 pp

Reed, C.A., \& Marx, H. (1959). A Herpetological Collection from Northeastern Iraq. Transactions of the Kansas Academy of Science, 62(1), 91-122.

Rohlf, F.J. (1999). Shape statistics: Procrustes superimpositions and tangent spaces. Journal of Classification, 16, 197-223.

Rohlf, F.J., \& Slice D.E. (1990). Extensions of the Procrustes method for the optimal superimposition of landmarks. Systematic Zoology, 39, 40-59.

Rohlf, F.J. (2000). Ntsys-Pc Version 2.1o. Numerical taxonomy and multivariate analysis system. Exeter Software.

Rohlf, F.J. (2003). TpsSMALL1.20. Department of Ecology and Evolution, State University of New York at Stony Brook.

Rohlf, F.J. (2004). TpsSUPER1.14. Department of Ecology and Evolution, State University of New York at Stony Brook.

Rohlf, F.J. (2007). TpsRELW1.45. Department of Ecology and Evolution, State University of New York at Stony Brook.

Rohlf, F.J. (2008). TpsDIG2.12. Department of Ecology and Evolution, State University of New York at Stony Brook. 
Rohlf, F.J. (2009). TpsUTIL1.44. Department of Ecology and Evolution, State University of New York at Stony Brook.

Schmidtler, J.F., \& Bischoff, W. (1995). Beziehungen Zwischen Lebensraum und Morphologie bei Lacerta cappadocica WERNER, 1902 in der Türkei. Die Eidechse, 6(14), 13-21.

Slice, D.E. (2007). Morpheus. Software for morphometric Research. Department of Ecology and Evolution, State University of New York, Stony Brook, New York.

Tchernov, E. (1992). The Afro-Arabian component in the Levantine mammalian fauna: a short biogeographical review. Israel Journal of Zoology, 38, 155-192.

Terent'ev, P.V., \& Chernov, S.A. (1949). Key to Amphibians and Reptiles. Jerusalem, Israel, Israel Programme for Scientific Translations, (1965).

Thomas, R., \& Hedges, S. B. (2007). Eleven new species of snakes of the genus Typhlops (Serpentes: Typhlopidae) from Hispaniola and Cuba. Zootaxa, 1400, 1-26.

Vidal, N., Marin, J., Morini, M., Donnellan, S., Branch, W.R., Thomas, R., Vences, M., ... \& Hedges, S.B. (2010). Blindsnake evolutionary tree reveals long history on Gondwana. Biology Letters, 6, 558-561.

Wallach, V., Brown, R.M., Diesmos, A.C., \& Gee, G.V.A. (2007). An Enigmatic New Species of Blind Snake from Luzon Island, Northern Philippines, with A Synopsis of The Genus Acutotyphlops (Serpentes: Typhlopidae). Journal of Herpetology, 41 (4), 690-702.

Werner, F. (1919). Reptilien und amphibien aus dem Amanus-Gebirge. Archiv für Naturgeschichte, 85, 130-141.

Werner, Y.L. (1971). Some Suggestions for the Standard Expression of Measurements. Systematic Zoology, 20(2), 249-252.

Werner, Y.L., \& Seifan, T. (2006). Eye size in geckos: asymmetry, allometry, sexual dimorphism, and behavioral correlates. Journal of Morphology, 67, 1486-1500.

Zelditch, M.L., Swiderski, D.L., Sheets, H.D., Fink, W.L. (2004). Geometric Morphometrics for Biologists: a Primer. London, England, Elsevier Academic Press, $443 \mathrm{pp}$. 


\section{APPENDIX}

Anatolian Population $(\mathrm{n}=275)$ :

ZDEU 1957/55 (n=11), Uşak; 1963/30, Aksaray; 1965/12, Güre village, Akçay/Balıkesir; 1970/22, Karapınar/Konya; 1970/94, Kula/Manisa; 1970/143, Meke tuzlası, Karapınar/Konya; 1976/65, Akseki/Antalya; 1976/88 (n=2), Meke tuzlası, Karapınar/Konya; 1997/26, Cemilli village/Mersin; 1977/41, İskenderun/Hatay; 1977/48, Kırıkhan/Hatay; 1977/98 (n=2), Cizre/Mardin; 1977/101 (n=7), Cizre/Mardin; 1977/130, Karaali village /Elazı̆̆; 1977/132 (n=2), Kömürler village/Elazığ; 1977/133 (n=3), Sürgü village/Malatya; 1977/136 (n=3), Malatya; 1977/147, Narlı/Kahramanmaraş; 1984/36 (n=2), $20 \mathrm{~km}$ to Marmaris/Muğla; 1986/10 (n=3), 20. km to Bitlis; $1986 / 33$ ( $\mathrm{n=2}$ ), Pamucak village, Marmaris/Muğla; 1990/9 (n=5), Çine/Aydın; 1991/43 (n=2), Çine/Aydın; 1993/29 (n=2), Aladağ/Konya; 1993/32 (n=3), Antakya/Hatay; 1993/37, Samandağ/Hatay; 1993/38 (n=2), Samandağ/Hatay; 1996/35 ( $n=7)$, Alahan village, Mut/Mersin; 1996/36 (n=2), Karaekşi village, Mut/Mersin; 1996/37 (n=2), Cemilli village/Mersin; 1996/39, Alahan village, Mut/Mersin; 1996/130, Meke tuzlası, Karapınar/Konya; 1997/96 (n=2), Yahyalı/Kayseri; 2001/9, Karaböğürtlen village, Köyceğiz/Muğla; 2004/40 (n=6), Çiğli/İzmir; 2006/159 (n=2), Üstüntaş village, Siverek/Şanlıurfa; 2007/31 ( $\mathrm{n=6}$ ), Yılankale mevkii, Ceyhan/Adana; 2007/36 (n=4), Arsuz/Hatay; $2007 / 69$ ( $\mathrm{n=2}$ ), Küplüce village/Kilis; 2007/84, Birecik/Şanlıurfa; 2007/95, Tek Tek Mountains/Şanlıurfa; $2007 / 98$ (n=4), Karakeçi village/Şanlıurfa; 2007/116, Başkonuş plateau/Kahramanmaraş; 2007/131, Bornova/İzmir; 2007/137, Üçkuyu village/Şanlıurfa; 2007/138 (n=4), Bornova/İzmir; 2007/140, Yörük village, İdil/Şırnak; 2007/149 (n=2), Yılankale mevkii, Ceyhan/Adana; 007/239, Gaziantep; 2008/13 (n=2), Yilankale mevkii, Ceyhan/Adana; 2008/15, Y1lankale mevkii, Ceyhan/Adana; 2008/25 (n=3), Çaybeyi village/Gaziantep; 2008/51, Taşucu/Mersin; $2008 / 52$ (n=2), Çermik/Diyarbakır; 2008/53 (n=5), Çermik/Diyarbakır; 2008/55, Eğil/Diyarbakır.

ZMHRU 2009/34 (n=3), Pamukkale/Denizli; 2009/35, Eğil/Diyarbakır; 2009/36, Kemenli village, Mut/Mersin; 2009/37 $(\mathrm{n}=2)$, Mut/Mersin; 2009/38 (n=3), Porsuk village, Ulukışla/Niğde; 2009/39, Çetinkuyu village, Eruh/Siirt; 2010/86, Baykan/Siirt; 2010/87, Boyunlu village, Silvan/Diyarbakır; 2010/88 (n=2), Çukurca/Hakkari; 2010/89 (n=2), Eğil/Diyarbakır; 2010/90(n=4), Silvan/Diyarbakır; 2010/91(n=2), Midyat/Mardin; 2010/92, Kınık/Antalya; 2011/7, Gölpınar village/Şanlıurfa; 2011/50, Gözeli village/Şanlıurfa; 2011/62, Savaşan village, Halfeti/Şanlıurfa; 2011/97, Evren village/Antalya; 2011/98 (n=2), Kargıcık village, Silifke/Antalya; 2011/106, Kartalan/Siirt; 2011/107, Gürpınar village/Şırnak; 2011/108 ( $n=2)$, Göynük village, Kemer/Antalya; 2011/109, Değirmendere village, Kemer/Antalya; 2011/110 (n=2), Beycik village, Kemer/Antalya; 2011/111 ( $n=2)$, Turunçova village, Finike/Antalya; 2011/112, Erentepe village, Kumluca/Antalya; 2011/113 ( $\mathrm{n=3}$ ), İncircik village, Kumluca/Antalya; 2011/114 ( $\mathrm{n=3}$ ), Pamukkale/Denizli; 2011/115 (n=10), İdil/Şırnak; 2011/116, Dağdere village, Tire/İzmir; 2011/117 (n=12), Türkönü village, Ödemiş/İzmir; 2011/159, Suruç/Şanlıurfa; 2011/160 (n=3), Çavuşlu village, Suruç/Şanlıurfa; 2011/161 (n=2), Otlukalan village/Şanlıurfa; 2011/162 (n=3), Büyükalan village/Şanlıurfa; 2011/163, Yollarbaşı village/Şanlıurfa; 2011/164 (n=3), Keçeli village, Viranşehir/Şanlıurfa; 2011/165 ( $\mathrm{n=6}$ ), Taşönü village, Viranşehir/Şanlıurfa; 2011/170, Suruç/Şanlıurfa; 2011/171(n=4), Savaşan village, Halfeti/Şanlıurfa; 2011/172 (n=2), Çukurca/Hakkari; 2011/173 (n=3), Siirt; 2011/174, Gaziantep; 2011/175, Antalya; 2011/176, Dereköy village, Kemalpaşa/İzmir; 2011/213, Pamukkale/Denizli; 2011/214, Leylekli village/Hatay; 2011/215, Afyon; 2012/61, Seferihisar/İzmir; 2012/63, Güzelbağ/Antalya; 2012/65, Türbelinaz/Antalya; 2012/67, Bornova/İzmir; 2012/68 (n=7), Yağmapınar village, Karapınar/Konya; 2012/69 (n=3), Saraydüzü/Afyon; 2012/95, Hasanbeyli/Osmaniye; 2012/101, Savaşan village, Halfeti/Şanliurfa; 2012/105, Ilıcalar/Bingöl; 2012/108, Gevaş/Van; 2012/117 (n=2), Melekli/Iğdır; 2012/127 (n=11), Yukarı Çı̆̆rıklı/Kars; 2013/52(n=3), Subaşı village, Kemaliye/Erzincan; 2013/61 ( $n=2)$, Gözeler village, Ovacık/Tunceli; $2013 / 62(n=4)$, Çemişkezek/Tunceli.

Cyprian Population $(\mathrm{n}=76)$ :

ZDEU 1989/36 (n=2), Lapta/Girne; 1994/72, Lapta/Girne; 1995/94 (n=2), Gönyeli; 1996/12 (n=9), Gönyeli; 2002/6 (n=9), Gönyeli; 2003/33 (n=2), Mehmetçik; 2007/8 (n=48), Gönyeli; 2008/57, Esentepe; 2008/58 (n=2), Gönyeli.

*Corresponding author: bahadirakmehotmail.com 